\title{
Względna przyczyna odwoławcza związana z błędem w rekonstruowaniu podstawy faktycznej orzeczenia w perspektywie prawnomiędzynarodowej i konstytucyjnej
}

\begin{abstract}
From the perspective of legal-international and constitutional guarantees of a two-instance procedure one should consider admissible the exclusion of the control of the actual basis in reference to guilt and punishment when such an adjudication constituted the object of a lawsuit-related contract, for the right to instance-based control of adjudications is relinquishable, and the limitations of the challengeability of contractual rulings was regulated in the Polish criminal procedure as not to exclude the right of the parties to bring about control of contractual rulings in a general manner, but only to constrain the catalogue of the admissible appeal-based accusations. However, the complete liquidation of the instance-based control of the establishment of the actual state of affairs contradicts the legal-international and constitutional guarantees, for the reconstruction of the actual state of affairs constitutes a component of the adjudication about someone's culpability in the trial-related sense, and the control of the solution of this problem is guaranteed at the international level. The abolishment of instance-based control of the establishment of the actual state of affairs, being a manifestation of the pursuit of praxeological economical arrangements, also results in the reduction of the probability of reaching material truth. Moreover, it changes the model of a multi-faceted verificationbased activities realised within the framework of a typical instance-based course into control which is similar to an analysis and correction peculiar to the extraordinary modes of control-related proceedings.
\end{abstract}

Key words: Appeal-related proceedings, error in the establishment of the actual state of affairs, contractual ruling, the two-instance nature of proceedings 


\section{Syntetyczne i analityczne definicje podstawy faktycznej wyroku}

Struktura logiczna wszystkich decyzji sądowego stosowania prawa ma postać tzw. sylogizmu prawniczego będącego na płaszczyźnie stosowania prawa egzemplifikacją sylogizmu decyzyjnego prostego. W jego konstrukcji można wyodrębnić trzy elementy:

1) przesłankę większą, dotyczącą znaczenia reguły prawnej znajdującej zastosowanie $\mathrm{w}$ konkretnym przypadku rozstrzygania (założeniem jest więc to, że określona norma przewidująca konsekwencje zaistnienia określonych faktów obowiązuje i ma ustalone znaczenie),

2) przesłankę mniejszą, odnoszącą się do faktów składających się na procesową rekonstrukcję zaszłości, w związku z którą toczy się proces karny (założeniem jest istnienie faktu sprawy objętego normą znajdująca zastosowanie in concreto) oraz

3) konkluzji rozstrzygającej sprawę według schematu, zgodnie z którym fakt zgodny z normą sprawy pociąga za sobą konsekwencje określone w tejże normie prawnej ${ }^{1}$.

Rozstrzygnięcie sprawy poprzez podjęcie decyzji sądowego stosowania prawa oznacza więc zastosowanie konsekwencji prawnych przewidzianych w normie prawnej znajdującej zastosowanie w ustalonym stanie faktycznym. Podstawa faktyczna sylogizmu prawniczego nie jest jednak pojęciem jednoznacznym, może być bowiem ujmowana w sposób syntetyczny lub analityczny. Syntetyczne rozumienie podstawy faktycznej rozstrzygnięcia obejmuje zakresem denotacji tej nazwy zarówno ustalone fakty, jak i przeprowadzone dowody oraz ich ocenę. Zbiorcze ujęcie podstawy faktycznej orzeczenia inkluduje w jej obręb całość procesu dowodzenia, który finalizuje deskrypcja faktu sprawy wyróżnionego normatywnie, odpowiadającą opisowi faktów prawnych określonych w hipotezie stosowalnej normy prawnej. Syntetycznie ujmowaną podstawę faktyczną stanowią więc fakty sprawy sprzężone z operacjami logicznymi i psychologicznymi do-

1 M. CIÉ́LAK: Dzieła wybrane. T. II: Polska procedura karna. Podstawowe założenia teoretyczne. W: M. CieśLAK: Dzieła wybrane. Red. S. Waltoś. Kraków 2011, s. 260; J. Gregorowicz: $Z$ problemów logicznych stosowania prawa (Résumé: Application de la Loi: Problémes Logiques). ZNUŁ 1963, seria I, z. 32, s. 5 i nast.; W. LANG, J. WróbleWsKI, S. ZawadzKI: Teoria państwa i prawa. Warszawa 1986, s. 474; K. OpaŁeK, J. WróblewsKi: Zagadnienia teorii prawa. Warszawa 1969, s. 308; J. WróBlewsKI: Sadowe stosowanie prawa. Warszawa 1972, s. 274; IDEM: Wartości a decyzja sądowa. Wrocław 1973, s. 37; IDEM: Stosowanie prawa (model teoretyczny). PiP 1967, z. 6, s. 375 i nast.; inne miejsce publikacji: J. WróblewsKi: Pisma wybrane. Red. M. ZIRK-SAdowsKI. WARsZAWa 2015, s. 313 i nast.; IdeM: O tak zwanym sylogizmie prawniczym. W: Zagadnienia prawa karnego i teorii prawa. Ksiega pamiatkowa ku czci Profesora W. Woltera. Warszawa 1959, s. 227 i nast.; Z. ZIEMBA: Logika deontyczna jako formalizacja rozumowań normatywnych. Warszawa 1969, s. 54 i nast. 
tyczącymi postępowania dowodowego oraz oceny dowodów ${ }^{2}$. Podstawa faktyczna sprawy ujmowana syntetycznie stanowi pojęcie o konotacji materialnoprocesowej, aspekt procesowy koncentruje się wokół procesu gromadzenia i selekcjonowania podstawy dowodowej orzeczenia oraz weryfikacji prawdziwościowej dowodów dopuszczalnych, natomiast perspektywa materialnoprawna akcentuje znaczenie zrekonstruowanej zaszłości zdatnej do poddania jej dalszym procesom decyzjotwórczym. Wcielenie do podstawy faktycznej rozstrzygnięcia procesu gromadzenia i aposteriorycznej oceny materiału dowodowego sfinalizowanego ustaleniem stanu faktycznego sprawy oznacza konsolidację różnych sekwencji sądowego stosowania prawa, wieloelementowa treść podstawy faktycznej rozstrzygnięcia jest więc wyrazem akceptacji dla globalnego, niezróżnicowanego sekwencyjnie traktowania faktów w procesie ${ }^{3}$. Emblematyczną definicję syntetycznie ujmowanej podstawy faktycznej rozstrzygnięcia sformułowała J. Klich-Rump, twierdząc tout court, że: „(...) w rozumieniu prawnoprocesowym podstawę faktyczną rozstrzygnięcia stanowią nie same tylko ścisłe ustalenia (wskazanie faktów ustalonych przez sąd), lecz także wskazanie przyczyn, dla których sąd tych ustaleń dokonał, a więc zajęcie przez sąd stanowiska wobec zgromadzonego materiału"4. Analityczne rozumienie podstawy faktycznej rozstrzygnięcia obejmuje zakresem denotacji tej nazwy wyłącznie ustalenia faktyczne dokonane przez sąd, ekskludując tym samym poza pojęcie podstawy faktycznej orzeczenia materiał faktyczny i związane z nim rozumowania o charakterze logicznym czy też psychologicznym, odnoszące się do aposteriorycznej oceny dowodów. Wąskie rozumienie faktycznej kanwy orzeczenia opiera się na ścisłej separacji rezultatu w postaci samych ustaleń faktycznych od materiału faktycznego i wszystkich operacji niezbędnych dla krytycznej rekonstrukcji historycznej faktów czy też ustaleń faktycznych ${ }^{5}$. Eksponentem tezy o konieczność oddzielenia ustaleń faktycznych od substratu dowodowego będącego przedmiotem rozumowań logicznych, quasi-logicznych oraz ocen jest W. Siedlecki. Autor ten twierdzi bowiem, że: „Podstawę faktyczną wyroku stanowi ustalony przez sąd w toku postępowania stan faktyczny sprawy. Ustalenie to jest w zasadzie wynikiem oceny dowodów przeprowadzonych przez sąd w cza-

2 J. JaśKiewicz: Poznanie faktów w postępowaniu cywilnym..., s. 110-111; J. KLICH-Rump: Podstawa faktyczna rozstrzygnięcia sądowego w procesie cywilnym. Warszawa 1977, s. 46; P. RYLSKI: Dziatanie sądu z urzędu a podstawa faktyczna wyroku cywilnego. Warszawa 2009, s. 154.

${ }^{3}$ K. PIASECKI: Wyrok pierwszej instancji $w$ procesie cywilnym. Warszawa 1981, s. 84. s. 155.

${ }^{4}$ J. KuIch-Rump: Podstawa faktyczna rozstrzygnięcia sadowego $w$ procesie cywilnym...,

${ }^{5}$ W. SIEDLECKI: Zarys postępowania cywilnego. Warszawa 1966, s. 318; Idem: Zasady wyrokowania $w$ procesie cywilnym. Warszawa 1957, s. 230; K. PIASECKI: Wyrok pierwszej instancji $w$ procesie cywilnym. Warszawa 1981, s. 84. 
sie procesu. Sąd bowiem, jak wyraźnie stanowi Kodeks, musi wskazać fakty, które uznał za udowodnione, i dowody, na których się oparł"6. Kształt podstawy faktycznej rozstrzygnięcia $\mathrm{w}$ wąskim rozumieniu będzie więc swoistym odbiciem deskrypcji faktów wyróżnionych normatywnie w hipotezie stosowalnej normy prawnej. Analityczne ujęcie faktycznej kanwy orzeczenia nie oznacza deprecjacji procesowego aspektu ustaleń faktycznych, ustalenie podstawy faktycznej wyroku ściśle łączy się przecież z całością pracy sądu w toku postępowania, w szczególności postępowania dowodowego, wąsko zakresowa definicja jedynie odmiennie rozkłada materialne i procesowe akcenty, podkreślając to, że podstawę faktyczną wyroku stanowi ustalony przez sąd $\mathrm{w}$ toku postępowania stan faktyczny rozpoznawanej sprawy. Skondensowana definicja faktycznych fundamentaliów sprawy akcentuje więc materialnoprawne konotacje faktów sprawy; ustalone fakty tkwiące $\mathrm{w}$ podstawie mają bowiem znaczenie jurydyczne przede wszystkim z perspektywy normy materialnej zawierającej deskrypcję jakiegoś faktu, z którego zaistnieniem prawo łączy określone konsekwencje. Materialne konotacje faktu sprawy podkreśla S. Kalinowski, wskazuje on bowiem in extenso, że: „W procesie dowodzenia, a więc $\mathrm{w}$ procesie poznawczym, zmierzającym do ustalenia prawdy rzeczywistej, interesują nas fakty, do stwierdzenia których dochodzimy poprzez ustalenia faktyczne"”. Analityczne ujęcie podstawy faktycznej rozstrzygnięcia jako jedyne koreluje z kwestyjnym ujęciem przedmiotu procesu karnego. W klasycznych kategoriach objaśniania genus proximum kwestyjnego ujęcia przedmiotu procesu karnego stanowi pewna kwestia prawna. W literaturze oznaczano ją synonimicznie jako sprawę prawną ${ }^{8}$, sprawę życiową, temat badania i rozstrzygnięcia ${ }^{9}$ czy też zagadnienie lub zespół zagadnień ${ }^{10}$. W pełni kwestyjną definicję przedmiotu procesu zaproponował M. Cieślak ${ }^{11}$, sugerując,

${ }^{6}$ W. SIEDLECKI: Zasady wyrokowania $w$ procesie cywilnym..., s. 230. W. Siedlecki twierdzi natomiast, że: „Sąd musi zająć stanowisko wobec całego materiału procesowego oraz uzasadnić jasno i należycie swoje zdanie, a w szczególności na jakiej podstawie uznał pewne fakty za prawdziwe (...). Wszelkie zaś luki i niejasności, które ujawnia się przy zestawieniu podstawy wyroku z materiałem procesowym, muszą budzić uzasadnioną wątpliwość, czy ustalenie podstawy faktycznej nastąpiło prawidłowo" - zob. W. SIEDLECKI: Zarys postępowania cywilnego..., s. 318.

${ }^{7}$ S. KaLINOWSKI: Polski proces karny $w$ zarysie. Warszawa 1981, s. 158.

${ }^{8}$ W. SAuER: Grundlagen des Prozessrechts. Stuttgart 1929, inne miejsce publikacji: „Scientia Verlag” 1970 (przedruk wydania z 1929 r.), s. 187.

${ }^{9}$ E. BeLING: Deutches Reichsstrafprozessrecht. Berlin-Lipsk 1928, s. 104 i nast.

${ }^{10}$ M. CIEŚLAK: O pojęciu przedmiotu procesu karnego i $w$ sprawie tzw. „podstawy procesu". W: M. CIEŚLAK: Dzieła wybrane. T. IV: Prawo karne procesowe. Artykuty, studia i inne prace. Red. S. Waltoś. Kraków 2011, s. 90, inne miejsce publikacji: PiP 1957, z. 8-9.

${ }^{11}$ Koncepcja M. Cieślaka bazowała na poglądach L. Schaffa; to w jego pracach pojawia się twierdzenie, zgodnie z którym autonomiczną cechę kwestii prawnej stanowiącej przedmiot procesu karnego, a więc tego, na ustalenie i rozstrzygnięcie czego nakierowany jest proces, 
by różnicy gatunkowej (differentia specifica) kwestii prawnej stanowiącej przedmiot procesu karnego upatrywać w tym, do czego się odnosi, tj. w odpowiedzialności prawnej za określony czyn przestępny. Odpowiedzialność karna rozumiana jako zasada ponoszenia ujemnych konsekwencji przewidzianych w ustawie karnej za popełnienie czynów, które są zabronione przez ustawę, opiera się na dwóch podstawach, tj. faktycznej i prawnej. Fundament faktyczny odpowiedzialności karnej stanowi czyn przestępny, natomiast prawną podstawą odpowiedzialności ustalanej $\mathrm{w}$ procesie są odpowiednie przepisy prawne ${ }^{12}$.

\section{Model kontroli odwoławczej wykluczający weryfikację faktów sprawy}

Z perspektywy teoretycznej instancyjna kontrola ustaleń tkwiących w podstawie faktycznej rozstrzygnięcia może być ukształtowana na różne sposoby, jeden z nich całkowicie wyklucza weryfikację faktów sprawy. Model został nadbudowany na heurystycznym założeniu o niemożności dokonania dyferencjacji pomiędzy naruszeniem prawa materialnego, wadliwością procedury i błędem w ustaleniach faktycznych. Ciąg wnioskowań prowadzących do tezy o niemożności autonomicznego zaskarżenia ustaleń faktycznych rozpoczyna założenie, zgodnie z którym błąd w ich rekonstrukcji może zaistnieć dopiero na etapie rozumowania w oparciu o całokształt prawidłowo ocenionego materiału dowodowego w procesie wolnym od uchybień proceduralnych ${ }^{13}$, a więc wówczas, gdy ustalenia faktyczne korelują z materiałem dowodowym ${ }^{14}$. Ponieważ równocześnie samoistny zarzut obrazy prawa materialnego i niewspółmierności kary można sformułować dopiero wówczas, gdy orzeczenie oparto na trafnych i niekwestionowanych ustaleniach faktycznych - wyeksplikowane wprost subiektywne twierdzenie o zaistnieniu błędu w ustaleniach faktycznych zawsze będzie się sprowadzało do pozbawionej argumentów prezentacji odmiennej oceny materiału dowodowego ${ }^{15}$. At consequences każdy błąd

stanowi orzekanie o istnieniu lub nieistnieniu obiektywnym (rzeczywistym) okoliczności czy przestępstwa, na którego byt powołuje się wersja oskarżenia. Zob. L. ScHaff: Wszczęcie postępowania karnego a problem podstawy i przedmiotu procesu. PiP 1959, z. 2, s. 247 i nast.; IDEM: Zakres i formy postępowania przygotowawczego. Warszawa 1961, s. 45 i nast.

${ }_{12}$ M. CIEŚLAK: O pojęciu przedmiotu procesu karnego i $w$ sprawie tzw. „podstawy procesu"..., s. 93; IDEm: Proces karny. Zagadnienia podstawowe. Kraków 1952, s. 46; IDEM: Przewodnik do nauki procesu karnego. Warszawa 1957, s. 100.

${ }^{13}$ Wyrok SA we Wrocławiu z dnia 28 grudnia 2005 r., II AKa 340/05, LEX nr 171971.

${ }^{14}$ H. Furmankiewicz, M. Majster, L. Penner: Akty oskarżenia i rewizje. Warszawa 1955, s. 113; J. WASZCZYŃsKi: O podstawach rewizji według k.p.k. ZNUŁ 1959, seria I, z. 14, s. 107.

${ }^{15} \mathrm{O}$ niedopuszczalności sprowadzenia zarzutu błędu w ustaleniach faktycznych stanowiących podstawę orzeczenia wyłącznie do forsowania własnej oceny materiału dowo- 
orzeczenia jest równocześnie błędem postępowania, komasacja obu rodzajów usterek jest możliwa w każdej konfiguracji - przebieg likwidujący konflikt prawny zgodnie z zasadą rzetelnego procesu koherentnie połączony z oceną zgromadzonego materiału odpowiednio do nakazów implikowanych logiką, doświadczeniem życiowym i wskazaniami wiedzy nie może wygenerować niepoprawnych z punktu widzenia procesowego rekonstrukcji faktycznych, prawnie relewantnych ${ }^{16}$, jakiekolwiek wadliwości popełnione $\mathrm{w}$ fazie decyzyjnej ostatecznie zaś można kwantyfikować jako przekroczenie uniwersalnej normy prawa procesowego, nakazującej arbitrowi rozsądzanie konfliktów prawnych stosownie do treści przepisów prawa (iudex secundum ius iudica) ${ }^{17}$. Reminiscencje poglądu o fuzji błędów postępowania i orzekania funkcjonują współcześnie zarówno $\mathrm{w}$ judykaturze ${ }^{18}$, jak i w doktrynie - w dziedzinie nauki stanowiąc teoretyczną podwalinę postulatu eliminacji z zakresu kontroli odwoławczej błędów popełnionych przy rekonstruowaniu faktów tkwiących u podstaw orzeczenia ${ }^{19}$. Poza pełną lub mającą miejsce w przeważającej liczbie

dowego zob. postanowienie SA z dnia 9 kwietnia 2008 r., V KK 301/07, LEX nr 398555; uchwała SN z dnia 10 maja 2007 r., SNO 24/07, LEX nr 568916; wyrok SN z dnia 3 kwietnia 2007 r., II KK 81/06, OSNwSK 2007, z. 1, poz. 758; wyrok SN z dnia 1 marca 2007 r., WA 8/07, OSNwSK 2007, z. 1, poz. 559; wyrok SN z dnia 10 maja 2005 r., 12/05, OSNwSK 2005, z. 1, poz. 949; wyrok SN z dnia 10 maja 2005 r., WA 10/05, OSNwSK 2005, z. 1, poz. 947; uchwała SN z dnia 23 czerwca 2003 r., SNO 40/03, LEX nr 568957.

${ }^{16}$ W. WASSERMAN: Zasady formułowania zarzutów apelacyjnych $w$ obowiazujacej procedurze karnej. Prok. i Pr. 2010, z. 6. Autor na potwierdzenie tezy zakładającej tożsamość naruszenia przepisów postępowania z błędami rekonstrukcji stanu faktycznego odwołuje się do orzeczeń Sądu Najwyższego, in casu stwierdzającego, że kontroli kasacyjnej podlegają nie same ustalenia faktyczne, lecz sposób ich dokonania, a błąd w ustaleniach faktycznych może stanowić podstawę kasacji, jeżeli jest następstwem rażącego naruszenia przepisów postępowania. Zob. postanowienie SN z dnia 13 lipca 2005 r., IV KK 57/05, postanowienie SN z dnia 13 grudnia 2005 r., II KK 375/05; postanowienie SN z dnia 7 grudnia 2004 r., V KK 336/04; postanowienie SN z dnia 14 października 2004 r., II KZ 44/04.

17 Teorię negującą odrębności błędów orzeczenia i postępowania sformułowano $\mathrm{w}$ doktrynie cywilnego prawa procesowego, oczywistym jest jednak jej ekstrapolacja na grunt procedowania w sprawach karnych. Zob. M. WALIGóRsKI: Podstawy kasacyjne procesu cywilnego $w$ świetle różnicy pomiędzy faktem i prawem. Lwów 1936, s. 60 i nast.

${ }^{18}$ In extenso teza z orzecznictwa: „Błąd w ustaleniach faktycznych jest jednoczesnym stwierdzeniem, że wystąpił jakiś błąd w zakresie dowodów. Chodzi o to, że istnieje z pewnością jakiś margines błędu w ustaleniach faktycznych niepowiązany z obrazą przepisów postępowania, ale margines ten jest bardzo wąski i może dać o sobie znać w wypadkach sporadycznych". Zob. Wyrok SO w Ostrołęce z dnia 9 października 2013 r II Ka 245/13, LEX nr 1718417.

${ }^{19}$ Takie założenie przyjęła M. Klejnowska, uznając dopuszczalność generalnego wyłączenia z zakresu kontroli odwoławczej stanu faktycznego, motywując wyrugowanie podstawy odwoławczej związanej bezpośrednio z faktami sprawy (art. 438 pkt 3 k.p.k.) ze względu na jej zbędność. Najczęściej bowiem w skardze odwoławczej formułowane są tzw. zarzuty mieszane, których istotę stanowi naruszenie przepisów procedury (art. 438 pkt 2 k.p.k.) generujące błędne ustalenia faktyczne - w konsekwencji zaś w skardze odwo- 
przypadków konsolidacją errores in procedendo i errores facti in iudicando współcześnie teza o generalnym wyabstrahowaniu kontroli instancyjnej od sprawdzania poprawności ustaleń faktycznych prakseologicznie ulega sprzężeniu z postulatem dążenia do przyspieszenia i usprawnienia procedury karnej, tak by opóźnione rozstrzygnięcie konfliktu prawnego nie niweczyło skutków możliwych do osiągnięcia przy działaniu bez zbędnej zwłoki (justice delayed is justice denied), a wyczekiwanie na wszczęcie i rozstrzygnięcie procedury likwidującej spór nie podważało zaufania co do tego, że prawo - w zamierzeniu służące organizacji życia zbiorowego posiada zdolność do przeciwstawiania się działaniom naruszającym istniejący stan rzeczy ${ }^{20}$. Trwała perspektywa dezaktualizacji instancyjnego kontrolowania ustaleń faktycznych motywowana dążeniem do realizacji prakseologicznych udogodnień oszczędnościowych może jednak generować obawy o zgodność stałego zamknięcia drogi do kontroli odwoławczej faktów sprawy z prawnomiędzynarodowym i konstytucyjnym wzorcem określającym zasadę dwuinstancyjnego modelu postępowania karnego ${ }^{21}$. Trwała perspektywa dezaktualizacji instancyjnego kontrolowania ustaleń faktycznych motywowana dążeniem do realizacji prakseologicznych udogodnień oszczędnościowych może jednak generować obawy o zgodność stałego zamknięcia drogi do kontroli odwoławczej faktów sprawy z prawnomiędzynarodowym i konstytucyjnym wzorcem określającym zasadę dwuinstancyjnego modelu postępowania karnego ${ }^{22}$.

ławczej apelujący niepotrzebnie mnoży zarzuty, inaczej je klasyfikując, choć dotyczą tego samego naruszenia. Zob. M. KlejnowsKa: Opinia dr hab. Moniki Klejnowskiej- Uniwersytet Rzeszowski. Model postępowania odwoławczego i nadzwyczajnoskargowego $w$ sprawach karnych. „Biuletyn Komisji Kodyfikacyjnej Prawa Karnego” 2010, z. 2, s. 82. Podobne stanowisko, jednak bez bliższego uzasadnienia, zajął A. Herzog. Zob. A. Herzog: Opinia Aleksandra Herzoga - Prokuratora Prokuratury Generalnej. Model postępowania odwoławczego oraz postępowania w sprawie nadzwyczajnych środków zaskarżenia. „Biuletyn Komisji Kodyfikacyjnej Prawa Karnego" 2010, z. 2, s.196.

${ }^{20}$ M. BorUCKA-ARctowa: Zaufanie do prawa jako wartość społeczna i rola sprawiedliwości proceduralnej. W: Teoria prawa. Filozofia prawa. Wspótczesne prawo i prawoznawstwo. Toruń 1998, s. 20; M. OssowsKa: Normy moralne. Próba systematyzacji. Warszawa 1985, s. 150; J. WróBlewski: Zmiany społeczne a prawo. PiP 1984, z. 11, s. 25; R.A. ToKARCZYк: Filozofia prawa $w$ perspektywie prawa natury. Białystok 1997, s. 199; IDEM: Prawo natury jako uniwersalna podstawa ładu społecznego. W: Filozofia prawa a tworzenie $i$ stosowanie prawa. Materiaty Ogólnopolskiej Konferencji Naukowej zorganizowanej $w$ dniach 11 i 12 czerwca 1991 r. w Katowicach. Red. B. Czech. Katowice 1992, s. 201; Z. ZIEMBIŃsKI: O pojmowaniu pozytywizmu i prawa natury. Poznań 1993, s. 89.

${ }^{21}$ S. STEINBORn: Ograniczenia zaskarżalności wyroku wydanego $w$ I instancji jako środek uproszczenia procesu karnego $w$ świetle prawa do dwuinstancyjnego postępowania (uwag de lege lata i de lege ferenda). W: Prawa człowieka: wczoraj - dziś - jutro. Red. J. ZaJADŁo. GSP 2005, t. XIII, s. 382; P. WiLIŃski: Proces karny w świetle Konstytucji. Warszawa 2011, s. 156.

${ }^{22}$ S. STEINBoRn: Ograniczenia zaskarżalności wyroku wydanego w I instancji jako środek uproszczenia procesu karnego $w$ świetle prawa do dwuinstancyjnego postępowania (uwag 


\section{Standardy międzynarodowe w zakresie korzystania z prawa do zaskarżenia wyroków w sprawach karnych}

Początkowo międzynarodowe fundamenty zabezpieczające zaskarżalność wyroków rozstrzygających w kwestii odpowiedzialności karnej ograniczały się do art. 14 ust. 5 Międzynarodowego Paktu Praw Obywatelskich i Politycznych ${ }^{23}$, gwarantującego każdej osobie skazanej za przestępstwo prawo odwołania się do sądu wyższej instancji w celu ponownego rozpatrzenia orzeczenia o winie i karze, zgodnie z ustawą. Podobnych gwarancji zabrakło w Konwencji o Ochronie Praw Człowieka i Podstawowych Wolności ${ }^{24}$, tekst Konwencji Europejskiej nie formułuje bowiem prawa do dwuinstancyjnego postępowania, konwencyjne standardy procesowe obejmują jedynie prawo dostępu do sądu w sprawach cywilnych i karnych oraz prawo do rozstrzygnięcia sprawy, kategoryzowane jako element szeroko rozumianego prawa do rzetelnego procesu, tj. procesu sprawiedliwego i publicznego, prowadzonego przez niezawisły i bezstronny sąd ustanowiony ustawą (art. 6 ust. 1 EKPC). Zarówno explicite, jak i implicite zasada rzetelnego procesu nie gwarantuje jednak dostępu do całego toku instancji, dostęp do sądu nie oznacza więc uprawnienia do żądania skontrolowania przez sąd wyższej instancji wydanego orzeczenia ${ }^{25}$. Zespół

de lege lata i de lege ferenda). W: Prawa człowieka..., s. 382; P. WilińsKi: Proces karny $w$ świetle Konstytucji. Warszawa 2011, s. 156.

${ }^{23}$ Międzynarodowy Pakt Praw Obywatelskich i Politycznych z dnia 19 grudnia 1966 r., ratyfikowany oświadczeniem rządowym z dnia 23 kwietnia 1977 r., Dz.U. 1977, nr 38, poz. 168 .

${ }^{24}$ Konwencja o Ochronie Praw Człowieka i Podstawowych Wolności sporządzona w dniu 4 listopada 1950 r. w Rzymie, ratyfikowana przez Rzeczpospolita Polską, tekst Europejskiej Konwencji o Ochronie Praw Człowieka i Podstawowych Wolności, zmienionej następnie Protokołami nr 3, 5 i 8 oraz uzupełnionej Protokołem nr 2, Dz.U. 1993, nr 61, poz. 284.

${ }^{25}$ Wyrok ETPC z dnia 23 lipca 1968 r. w sprawie Belgian Linguistic Case; wyrok ETPC z dnia 17 stycznia 1970 r. w sprawie Delcourt p. Belgii (skarga nr 2689/65); decyzja ETPC z dnia 1 lipca 1998 r. w sprawie Kopczyński p. Polsce (skarga nr 28863/95); wyrok ETPC z dnia 29 lipca 1998 r. w sprawie Omar p. Francji; wyrok ETPC z dnia 14 grudnia 1999 r. w sprawie Khalfaoui p. Francji (skarga nr 34791/97); decyzja ETPC z dnia 10 lutego 2000 r. w sprawie Stawicki p. Polsce (skarga nr 47711/99); wyrok ETPC z dnia 11 października 2001 r. w sprawie Hoffman p. Niemcom; wyrok ETPC z dnia 11 października 2001 r. w sprawie Sommerfeld p. Niemcom; wyrok ETPC z dnia 14 lutego 2007 r. w sprawie Louis p. Francji (skarga nr 44301/02). Zob. też P. HofMAŃski: Europejska Konwencja Praw Człowieka $i$ jej znaczenie dla prawa karnego materialnego, procesowego $i$ wykonawczego. Białystok 1993, s. 250; P. HofmańsKi, A. WróBel. W: Konwencja o Ochronie Praw Człowieka i Podstawowych Wolności. Komentarz do art. 1-18. T. I. Red. L. GARLICKI. Warszawa 2010, s. 289; T. JuRczYK: Prawa jednostki w orzecznictwie Europejskiego Trybunału Sprawiedliwości. Warszawa 2009, s. 97 i nast.; M.A. Nowicki: Wokół Konwencji Europejskiej. Komentarz do Europejskiej Konwencji Praw Człowieka. Warszawa 2017, s. 492; F. RadoniEwicz: Prawo do 
obowiązujących Polskę standardów międzynarodowych gwarantujących zaskarżalność wyroków rozstrzygających w kwestii odpowiedzialności karnej został uzupełniony po ratyfikacji Protokołu nr 7 do Konwencji o Ochronie Praw Człowieka i Podstawowych Wolności ${ }^{26}$. Art. 2 ust. 1 Protokołu poszerzył bowiem minimalny poziom konwencyjnych gwarancji karnoprocesowych, konstytuując prawo każdego, kto został przez sąd pierwszej instancji uznany za winnego popełnienia przestępstwa, w prawo do rozpatrzenia przez są wyższej instancji jego sprawy, tak w przedmiocie orzeczenia o winie, jak i co do kary. Prawie homogeniczne w swej treści przepisy art. 14 ust. 5 Międzynarodowego Paktu Praw Obywatelskich i Politycznych oraz art. 2 ust. 1 Protokołu nr 7 statuują międzynarodowy wzorzec zaskarżalności orzeczeń, określając przedmiotowy i podmiotowy zakres zastosowalności międzynarodowych gwarancji dwuinstancyjnego procesu oraz zakres kontroli orzeczenia w postępowaniu odwoławczym. Przedmiotowy zakres prawnomiędzynarodowych wzorców określających zasadę dwuinstancyjnego modelu postępowania karnego obejmuje jedynie wyroki sądowe uznające oskarżonego za winnego popełnienia przestępstwa, tj. wyroki skazujące oraz inne orzeczenia oparte na pewnym ustaleniu co do sprawstwa i winy, których następstwem nie jest jednak wymierzenie kary ${ }^{27}$, exempli gratia wyroki warunkowo umarzające postępowanie ${ }^{28}$. Przynależność kategorialna do orzeczeń objętych prawno-

sadu w Europejskiej Konwencji Praw Człowieka, Karcie Praw Podstawowych Unii Europejskiej oraz Konstytucji Rzeczpospolitej Polskiej - zagadnienia wybrane (cz. I). „Przegląd Prawa Konstytucyjnego" 2017, z. 2, s. 161 i nast.

${ }^{26}$ Protokół numer 7 do Konwencji o Ochronie Praw Człowieka i Podstawowych Wolności sporządzonego w dniu 22 listopada 1984 r. w Strasburgu. Protokół został ratyfikowany przez Rzeczpospolitą Polską, tekst ujednolicony, uwzględniający zmiany wprowadzone Protokołem numer 11 do Konwencji o Ochronie Praw Człowieka i Podstawowych Wolności opublikowano w Dz.U. 2003, nr 42, poz. 364.

27 P. van DiJK, G.J.H. van Hoof: Theory and Practice of the European Covnvention on Human Rights. The Hague 1996, s. 685 i nast.; P. HofMAŃsKI. W: Konwencja o Ochronie Praw Człowieka i Podstawowych Wolności. Komentarz do art. 19-59 oraz do Protokołów dodatkowych. T. II. Red. L. GARLICKI. Warszawa 2011, s. 632; S. STEInborn: Ograniczenie zaskarżalności wyroku wydanego w I instancji jako środek uproszczenia procesu karnego $w$ świetle prawa do dwuinstancyjnego postępowania (uwagi de lege lata i de lege ferenda). W: Gdańskie Studia Prawnicze. Prawa człowieka..., s. 365.

${ }^{28} \mathrm{O}$ tym, że wyrok warunkowo umarzający postępowanie obala domniemanie niewinności zob. E. SKR̨̨тоwicz: Charakter prawny orzeczenia warunkowo umarzajacego postępowanie karne $w$ świetle zasady domniemania niewinności. W: Wspótczesny polski proces karny. Ksiega ofiarowana Profesorowi Tadeuszowi Nowakowi. Red. S. STACHowiak. Poznań 2002, s. 19 i nast.; A. TĘCZA-PACIOREK: Zasada domniemania niewinności w polskim procesie karnym. Warszawa 2012, s. 245 i nast.; A. WĄSEK: Krytyczne uwagi do wyroku Trybunatu Konstytucyjnego z dnia 16 maja 2000, P 1/99, dotyczacego warunkowego umorzenia postępowania karnego. W: Współczesny polski proces karny. Księga ofiarowana..., s. 23. Ł. WoźNIAK: Zasada domniemania niewinności - zagadnienia podstawowe. W: Zasady procesu karnego 
międzynarodową gwarancją kontroli instancyjnej jest niezależna od nomenklatury użytej dla nazwania czynu zabronionego, przestępstwo jako instytucja prawna nie jest bowiem konstytuowane przez semantykę języ$\mathrm{ka}^{29}$, tylko przez samą naturę czynu oraz stopień surowości kary grożącej za realizację jego znamion ${ }^{30}$. Kategoryzowanie zakresu przedmiotowego prawnomiędzynarodowego standardu instancyjnych środków odwoławczych abstrahuje też od rodzaju sądu ferującego karę, międzynarodowe prawo do dwuinstancyjnego postępowania dotyczy więc zarówno orzeczeń sądów karnych, jak i administracyjnych ${ }^{31}$, w tym orzeczeń sądów dyscyplinarnych ${ }^{32}$. Z perspektywy podmiotowej standard dwuinstancyj-

wobec wyzwań wspótczesności. Księga ku czci Profesora Stanisława Waltosia. Red. J. CzAPSKA et al. Warszawa 2000, s. 356 i nast.

${ }^{29} \mathrm{~W}$ orzecznictwie strasburskim konsekwentnie przyjmuje się, że uzależnienie zastosowalności gwarancji w zakresie zaskarżalności orzeczeń w sprawach karnych od sposobu nazwania czynu zabronionego przez ustawodawcę krajowego prowadziłoby do wyłączenia standardu międzynarodowego dowolną i arbitralną decyzją państwa. Tak duża swoboda implikowałaby rezultaty sprzeczne z przedmiotem i celem Konwencji. Zob. wyrok ETPC z dnia 28 czerwca 1984 r. w sprawie Cambell i Fell p. Wielkiej Brytanii; wyrok ETPC z dnia 8 czerwca 1976 r. w sprawie Engell i inni p. Holandii; wyrok ETPC z dnia 2 września 1998 r. w sprawie Laukov p. Słowacji; wyrok ETPC z dnia 2 września 1998 r. w sprawie Kadubec p. Słowacji; wyroku ETPC z dnia 30 sierpnia 2016 r. w sprawie Igor Pascari p. Mołdowii.

${ }^{30}$ Raport Komisji z dnia 4 marca 1978 r. w sprawie Eggs p. Szwajcarii (skarga nr 7341/76), w którym stwierdzono że nie można uznać za przestępstwo czynu zagrożonego karą 5 dni ścisłego aresztu; z kolei w wyroku ETPC z dnia 3 października 2013 r. w sprawie Kasparov p. Rosji (skarga nr 21613/07) za sprawę karną uznano przypadek zastosowania aresztu administracyjnego, w ramach którego skarżący byli przetrzymywani tylko przez 2 godziny, ale mającego konotacje karne ze względu na to, że zarzut obejmował popełnienie wykroczenia polegającego na udziale w nielegalnej manifestacji. Na surowość kary jako kryterium definiujące przestępstwo Trybunał zwrócił uwagę także w wyroku z dnia 8 czerwca 1976 r. w sprawie Engel i inni p. Holandii oraz w wyroku z dnia 21 lutego 1984 r. w sprawie Öztürk p. Niemcom. Z kolei w decyzji Komisji z dnia 31 sierpnia 1999 r. w sprawie Hubner p. Austrii (skarga nr 34311/96) uznano, że ze względu na surowość grożącej kary art. 2 ust 1 Protokołu nr 7 może znaleźć zastosowanie także w przypadku skazania za wykroczenie.

${ }^{31}$ W wyroku ETPC z dnia 6 września 2005 r. w sprawie Gurepka p. Ukrainie za decyzję objętą standardem strasburskim uznano orzeczenie sądu administracyjnego nakładające izolacyjną sankcję o charakterze administracyjnym; z kolei w wyrokach ETPC z dnia 15 listopada 2007 r. w sprawie Galstyan p. Armenii oraz z dnia 17 lipca 2008 r. w sprawie Ashughyan p. Armenii za orzeczenia zaskarżalne w świetle art. 2 ust. 1 Protokołu nr 7 uznano decyzje administracyjne nakładające karę porządkową o charakterze izolacyjnym (areszt 15 dni); wyrokiem ETPC z dnia 23 września 1998 r. w sprawie Maligne p. Francji uznano, że obowiązujący we Francji środek polegający na odejmowaniu punktów za naruszenie przepisów o ruchu drogowym ze względu na swój prewencyjny i represyjny charakter stanowi karę karną, której wymierzenie podlega zaskarżeniu w oparciu o art. 2 ust. 1 Protokołu nr 7.

${ }_{32}$ M. KŁopocka-JasińsKa: Pojęcie sprawy $w$ świetle art. 6 Konwencji o Ochronie Praw Człowieka i Podstawowych Wolności. „Przegląd Prawa Konstytucyjnego” 2016, z. 3, s. 301 
nej kontroli prawidłowości wyroków skazujących wydanych w sprawach karnych jest mocno ograniczony, pełne prawo do sądu przysługuje bowiem jedynie oskarżonemu, gwarancje zaskarżalności nie obejmują natomiast strony czynnej procesu karnego oraz pokrzywdzonego niebędącego stroną $^{33}$. Regulacje prawnomiędzynarodowe dotyczące zakresu kontroli orzeczenia w postępowaniu odwoławczym przewidują zróżnicowany zakres weryfikacji orzeczeń uznających winę oskarżonego, w art. 14 ust. 5 Międzynarodowego Paktu Praw Obywatelskich i Politycznych zadekretowano in extenso, że przedmiotem zaskarżenia musi być jednocześnie zarówno rozstrzygnięcie $\mathrm{w}$ kwestii winy, jak i rozstrzygnięcie $\mathrm{w}$ przedmiocie wymierzonej kary, oba elementy objęte zakresem kontroli sądu odwoławczego łączy bowiem spójnik ,i” (and), kategoryzowany w logice zdań jako funktor koniunkcji. Z kolei w art. 2 ust. 1 Protokołu nr 7 zadekretowano, że zakres działalności sprawdzającej i korygującej obejmuje rozstrzygnięcie co do winy lub rozstrzygnięcie co do kary. Użycie w przepisach eksplikujących rozstrzygnięcia podlegającego kontroli instancyjnej spójnika „lub” (or), będącego funktorem alternatywy nierozłącznej, sugeruje dopuszczalność ograniczenia kontroli sądu odwoławczego tylko do jednego z elementów orzeczenia objętych gwarancją zaskarżalności, ponieważ zaś ontologicznie nie jest możliwa sytuacja kwestionowania rozstrzygnięcia $\mathrm{w}$ kwestii dotyczącej przypisania odpowiedzialności za przestępstwo bez jednoczesnego podważania orzeczenia $\mathrm{w}$ przedmiocie wymierzonej kary, dopuszczalne zawężenie zakresu kontroli odwoławczej gwarantowanej prawnomiędzynarodowymi standardami może dotyczyć jedynie ograniczenia postępowania instancyjnego do kwestii wymiaru kary. Konwencyjny wzorzec prawa do zaskarżenia pierwszoinstancyjnego rozstrzygnięcia gwarantuje więc różne warianty zbadania przez sąd wyższej instancji, prawnomiędzynarodowy standard w zakresie kontroli odwoławczej obejmuje bowiem zaskarżalność orzeczenia o karze oraz jednocześnie orzeczenia w przedmiocie winy i rozstrzygnięcia co do kary ${ }^{34}$.

i nast.; M. WĄSEK-WiAdEREK: Zastosowanie gwarancji art. 6 Europejskiej Konwencji Praw Człowieka do postępowań dyscyplinarnych (ze szczególnym uwzględnieniem odpowiedzialności dyscyplinarnej zawodów prawniczych). Rej. 2010, wyd. specjalne, s. 73; A. WasILEWsKI: Prawo do sadu $w$ sprawach dyscyplinarnych (ustawodawstwo polskie na tle standardów Europejskiej Konwencji Praw Człowieka i Podstawowych Wolności oraz Konstytucji). PS 2001, z. 9, s. 27.

${ }_{33}$ Decyzja Komisji z dnia 16 maja 1985 r. w sprawie Wallen p. Szwecji (skarga nr 10877/84).

34 Odmiennie przyjmuje S. Steinborn, jego zdaniem konwencyjny standard przewidziany w art. 2 ust. 1 Protokołu nr 7 obejmuje zbadanie przez sąd wyższej instancji orzeczenia o winie lub o karze lub też zarówno o winie, jak i o karze. Zob. S. STEINBorn: Ograniczenia zaskarżalności wyroku wydanego w I instancji jako środek uproszczenia proce- 
Standardy międzynarodowe w zakresie korzystania z prawa do zaskarżenia pierwszoinstancyjnego rozstrzygnięcia nie mają charakteru absolutnego, istnieją bowiem zadekretowane $\mathrm{w}$ regulacjach międzynarodowych przypadki zezwoleń na wyłączenie w porządku krajowym zasady kontroli instancyjnej, ponadto zaś art. 14 ust. 5 Międzynarodowego Paktu Praw Obywatelskich i Politycznych oraz art. 2 ust. 1 zd. 2 Protokołu nr 7 nie wykluczają na poziomie ustawodawstwa wewnętrznego państw-sygnatariuszy limitów zawężających dwuinstancyjny przebieg procesu karnego. Verba legis wskazano bowiem, że realizacja prawa zaskarżalności wyroków skazujących w sprawach karnych, ukonstytuowanego w art. 14 ust. 5 Międzynarodowego Paktu Praw Obywatelskich i Politycznych, następuje zgodnie z ustawą; wyraźny zapis konwencyjny określa również, że ustawa ma skodyfikować korzystanie z prawa do odwołania statuowanego $\mathrm{w}$ standardzie strasburskim, a w tym zasady, według których prawo to może być wykonywane ${ }^{35}$.

Posługując się kryterium możliwości trwałego odstąpienia od zasady zaskarżalności orzeczeń, można dokonać dyferencjacji prawnomiędzynarodowych gwarancji dostępu do instancji odwoławczej na bezwzględne i względne. Najbardziej restryktywne są zabezpieczenia statuowane art. 14 ust. 5 Międzynarodowego Paktu Praw Obywatelskich i Politycznych, normowane nim prawo oskarżonego do zakwestionowania wyroków skazujących za przestępstwo jest absolutne i nie może zostać wyłączone na poziomie ustawodawstwa wewnętrznego państw-sygnatariuszy. Już jednak mechanizm gwarancyjny wynikający z art. 2 ust. 1 Protokołu nr 7 do Konwencji o Ochronie Praw Człowieka i Podstawowych Wolności może zostać obniżony, regułę instancyjnej zaskarżalności wyroków skazujących można bowiem wyłączyć $\mathrm{w}$ porządkach krajowych w trzech przypadkach (art. 2 ust. 2 zd. 2). In extenso zadekretowano, że nie jest niezgodne z prawnomiędzynarodowymi gwarancjami wyłączenie prawa do zaskarżenia wyroku stwierdzającego winę oskarżonego w sprawach o drobne przestępstwa określone $\mathrm{w}$ ustawie, tj. o czyny niezagrożone karą izolacyjną ${ }^{36}$, których przynależność kategorialną należy oceniać zależnie od

su karnego $w$ świetle prawa do dwuinstancyjnego postępowania (uwag de lege lata i de lege ferenda). W: Gdańskie Studia Prawnicze. Prawa człowieka..., s. 371.

35 J. Pradel: Rzetelny proces $w$ Europejskim prawie karnym. Prok. i Pr. 1996, z. 9, s. 11.

${ }^{36}$ W wyroku ETPC z dnia 23 kwietnia 2009 r. w sprawie Kamburov p. Bułgarii (skarga nr 31001/02) uznano, że czyn karalny, za który prawo przewiduje kare grzywny lub aresztu do 15 dni, nie może być uznany za czyn drobny w rozumieniu art. 2 ust. 2 zd. 2 Protokołu nr 7 do Konwencji o Ochronie Praw Człowieka i Podstawowych Wolności. Podobnie przyjęto w wyroku ETPC z dnia 1 października 2009 r. w sprawie Stanchev p. Bułgarii (skarga nr 8682/02). 
surowości kary grożącej lub rzeczywiście wymierzonej ${ }^{37}$, a także a maiori ad minus czyny drobniejsze i niekwalifikowane jako przestępstwa w rozumieniu prawa krajowego i standardu konwencyjnego ${ }^{38}$. Drugi wyjątek umożliwiający odstąpienie od kontroli instancyjnej jest możliwy w razie, gdy ze względu na rangę danej osoby objętej specjalnymi procedurami (prezydent, premier czy ministrowie) lub rodzaj zarzuconego przestępstwa doszło do pierwszoinstancyjnego skazania przez Sąd Najwyższy ${ }^{39}$. Rezygnacja z zabezpieczeń zaskarżalności wyroków skazujących w sprawach karnych jest ponadto dopuszczalna, gdy dana osoba została uznana za winną i skazana w wyniku zaskarżenia wyroku uniewinniającego sądu pierwszej instancji, etiologia wyjątku zaskarżalności skazania w rezultacie zakwestionowania wyroku uniewinniającego wiąże się z dążeniem do uniknięcia mnożenia instancji. U podstaw dopuszczenia derogacji prawa do instancji odwoławczej legło bowiem założenie, że zachowanie zasady dwuinstancyjnego postępowania w sytuacji skazania przez sąd odwoławczy kontrolujący wyrok uniewinniający oznaczałoby de facto otwarcie oskarżonemu drogi do trzeciej instancji ${ }^{40}$.

Zapisy dopuszczające możliwość wewnątrzkrajowego regulowania zasady instancyjnej kontroli orzeczeń z jednej strony oznaczają obowiązek unormowania na poziomie ustawodawstwa wewnętrznego państw-stron Międzynarodowego Paktu Praw Obywatelskich i Politycznych oraz Protokołu nr 7 procedury odwoławczej, z drugiej zaś pozostawiają sygnatariuszom pewien zakres swobody co do wewnątrzkrajowego kształtowania przedmiotowego i podmiotowego obszaru zastosowalności międzynarodowych gwarancji dwuinstancyjnego procesu oraz co do zasięgu kontroli orzeczenia w postępowaniu odwoławczym czy też warunków formalnych, jakie musi spełniać skarżący, bądź też terminów, jakie po-

${ }^{37} \mathrm{~W}$ orzecznictwie Trybunału brak jest jednolitości w zakresie kryterium wiążące się ze stopniem surowości sankcji, in casu Trybunał stosuje bowiem zarówno kryterium odwołujące się do wysokości kary grożącej, jak i kryterium oparte na wysokości kary efektywnie wymierzonej. Pierwsze kryterium zdecydowało o uznaniu za drobne przestępstwo czynu, za który wymierzono karę 200 franków szwajcarskich (postanowienie ETPC z dnia 28 czerwca 1995 r. $w$ sprawie Arx-Derungs p. Szwajcarii), drugie było podstawą zakwalifikowania do kategorii drobnych przestępstw czynu, za który wymierzono karę 100 franków szwajcarskich przy maksymalnym zagrożeniu do 3 miesięcy pozbawienia wolności (postanowienie ETPC z dnia 5 kwietnia 1995 r. w sprawie LKD p. Szwajcarii).

${ }^{38} \mathrm{~W}$ postanowieniu ETPC z dnia 3 grudnia 1993 r. w sprawie Putz p. Austrii (skarga nr 18892/91) uznano, że dopuszczalne jest wyłączenie standardu dwuinstancyjnego postępowania w razie wymierzenia pieniężnej kary porządkowej przez sąd.

${ }^{39}$ Wyrok ETPC z dnia 18 grudnia 1980 r. w sprawie Crociani p. Włochom; wyrok ETPC z dnia 22 czerwca 2000 r. w sprawie Coëme i inni p. Belgii.

${ }^{40}$ P. Hofmański. W: Konwencja o Ochronie Praw Człowieka i Podstawowych Wolności. Komentarz do art. 19-59 oraz do Protokołów dodatkowych. T. II..., s. 640. 
winien zachować. Obowiązek wprowadzenia wewnątrzkrajowych regulacji udostępniających procedurę odwoławczą wynika z jego istotności ${ }^{41}$, standard międzynarodowy uznaje bowiem prawo do zaskarżenia pierwszoinstancyjnych orzeczeń za niezbędny komponent demokratycznego społeczeństwa ${ }^{42}$. Swoboda normowania zasady zaskarżalności na poziomie ustawodawstwa wewnętrznego ma jednak charakter kontrolowany, ostateczna ocena tego, czy ograniczenia nałożone w krajowych porządkach prawnych spełniają prawnomiędzynarodowy standard kontroli instancyjnej, stanowi bowiem kompetencję Europejskiego Trybunału Praw Człowieka realizowaną in casu $^{43}$. Kryterium oceny zachowania koherencji pomiędzy prawnomiędzynarodowymi gwarancjami dwuinstancyjnego postępowania i wewnątrzkrajowymi regulacjami zasady zaskarżalności orzeczeń stanowi to, czy wprowadzony na poziomie krajowym środek weryfikacji orzeczeń implikuje skutki zbieżne z wymogami międzynarodowymi ${ }^{44}$. W orzecznictwie strasburskim wskazano jedynie warunki brzegowe wewnętrznego ustawodawstwa krajowego ograniczającego zaskarżalność - ogół endemicznych ograniczeń nie może przekształcać realnego prawa do uruchomienia postępowania kontrolnego przed sądem usytuowanym w hierarchicznej strukturze sądownictwa na wyższym poziomie w uprawnienie fasadowe ${ }^{45}$, de facto uniemożliwiające skuteczną naprawę błędów sądów niższej instancji ${ }^{46}$, czy też uzależnione od arbi-

${ }^{41}$ Orzeczenie ETPC z dnia 21 lutego 1975 r. w sprawie Golder p. Wielkiej Brytanii, seria A, nr 18.

42 Orzeczenie ETPC z dnia 9 października 1979 r. w sprawie Airey p. Irlandii, seria A, nr 32; Orzeczenie ETPC z dnia 26 października 1984 r. w sprawie De Cubber p. Belgii; orzeczenie ETPC z dnia 13 maja 1989 r. w sprawie Artico p. Włochom, seria A, nr 37.

${ }^{43}$ Wyrok ETPC z dnia 19 maja 2009 r. w sprawie Kulikowski p. Polsce (skarga nr 18353/03); wyrok ETPC z dnia 22 marca 2007 r. w sprawie Siałkowska p. Polsce oraz w sprawie Staroszczyk p. Polsce (skarga nr 59519/00).

${ }^{44}$ Orzeczenie ETPC z dnia 29 marca 2006 r. w sprawie Scordino p. Włochom (skarga nr 36813/97).

${ }^{45}$ Orzeczenie ETPC z dnia 24 października 1979 r. w sprawie Winterwerp p. Holandii; orzeczenie ETPC z dnia 2 grudnia 1985 r. w sprawie Welter p. Szwecji; decyzja Komisji z dnia 9 września 1992 r. w sprawie Nielsen p. Danii (skarga nr 19028/91); decyzja ETPC z dnia 22 października 2002 r. w sprawie Hewitson p. Wielkiej Brytanii (skarga nr 50015/99); wyrok ETPC z dnia 30 października 2014 r. w sprawie Shvydka p. Ukrainie (skarga nr 17888/12); decyzja ETPC z dnia 1 września 2015 r. w sprawie Dorado Baúlde p. Hiszpanii (skarga nr 23486/12). We wszystkich orzeczeniach Trybunał uznał, że regulacje wewnątrzkrajowe muszą gwarantować możliwość skutecznej kontroli przez sąd odwoławczy procesu odbywającego się przed sądem in meriti.

${ }^{46} \mathrm{~W}$ wyroku ETPC z dnia 30 października 2014 r. w sprawie Shvydka p. Ukrainie (skarga nr 17888/12) stwierdzono, że standardy prawnomiędzynarodowe w zakresie dostępu do sądu odwoławczego narusza wprowadzenie w porządku krajowym apelacji o charakterze niesuspensywnym, tj. implikującej natychmiastowe wykonanie wyro$\mathrm{ku}$, a w konsekwencji rozpoznawanej dopiero po odbyciu przez skazanego całości kary. 
tralnej decyzji władz oraz pozbawione wyraźnie zdefiniowanej procedury i terminów ${ }^{47}$. Poza zakazem przekształcenia realnej kontroli spowodowania kontroli instancyjnej w model symulujący rzeczywistą weryfikację wymogiem wszelkich limitów lokalnych jest uzasadniony cel ograniczeń wprowadzonych $\mathrm{w}$ takim zakresie, by zachować rozsądne proporcje pomiędzy docelowym stanem mającym stanowić efekt restrykcji a środkami ograniczającymi zaskarżalność oraz nie wyłączać ścisłej istoty prawa do spowodowania kontroli instancyjnej ${ }^{48}$. Wewnątrzkrajowe regulacje mogą więc ograniczyć katalog przyczyn stanowiących podstawę zakwestionowania orzeczenia objętego gwarancją zaskarżalności, exepmli gratia zawężając go do naruszeń procedury lub uzupełniając o kontrolę ustaleń faktycznych ${ }^{49}$. Ze względu na to, że w regulacjach prawnomiędzynarodowych poszczególne zaskarżalne elementy orzeczenia łączy alternatywa nierozłączna, de nomine zgodne z wzorcem międzynarodowym wydaje się być także zawężenie zakresu kontroli odwoławczej do kwestii wymiaru kary. Malgré lui pełne wyłączenie kontroli instancyjnej rozstrzygnięcia w zakresie winy wydaje się być niezgodne z prawnomiędzynarodowym wzorcem dwuinstancyjnego postępowania, nie można bowiem co prawda zupełnie ignorować alternatywnego sposobu wskazania elementów orzeczenia podlegających kontroli, zakładając, że przedmiotem zaskarżenia musi być jednocześnie zarówno rozstrzygnięcie w kwestii winy, jak i rozstrzygnięcie $\mathrm{w}$ przedmiocie wymierzonej kary $^{50}$, jednak ukształtowanie zakresu

Niezgodność stwierdzono, mimo że skazany miał możliwość uzyskania odszkodowania w razie uchylenia przez sąd odwoławczy wyroku, w takiej konfiguracji prawo do odszkodowania stanowi bowiem tylko substytut prawa do odwołania nakierowanego na kontrolę prawidłowości orzeczenia wydanego w pierwszej instancji.

${ }^{47}$ Decyzja Europejskiej Komisji z dnia 6 października 1982 r., D.R., nr 31, s. 223; Wyrok ETPC z dnia 6 września 2005 r. w sprawie Gurepka p. Ukrainie (skarga nr 61406/00); wyrok ETPC z dnia 15 listopada 2007 r. w sprawie Galstyan p. Armenii (skarga nr 26986/03); wyrok ETPC z dnia 2 października 2012 r. w sprawie Kakabadze i inni p. Gruzji (skarga nr 1484/07).

${ }^{48}$ Decyzja ETPC z dnia 26 października 1995 r. w sprawie E.M. p. Norwegii (skarga nr 20087/92); orzeczenie ETPC z dnia 13 lutego 2000 r. w sprawie Krombach p. Francji (skarga nr 29731/96); decyzja ETPC z dnia 29 czerwca 2000 r. w sprawie Poulsen p. Danii (skarga nr 32092/96); orzeczenie ETPC z dnia 25 lutego 2002 r. w sprawie Papon p. Francji (skarga nr 54210/00); wyrok ETPC z dnia 6 września 2005 r. w sprawie Gurepka p. Ukrainie (skarga nr 61406/00); wyrok ETPC z dnia 15 listopada 2007 r. w sprawie Galstyan p. Armenii (skarga nr 26986/03); wyrok ETPC z dnia 4 czerwca 2015 r. w sprawie Ruslan Yakovenko p. Ukrainie (skarga nr 5425/11). We wszystkich judykatach uznano, że przy zachowaniu istoty prawa do spowodowania kontroli instancyjnej ograniczeń w zakresie zaskarżalności orzeczenia skazującego są dopuszczalne.

${ }^{49}$ P. van DiJK, G.J.H. van Hoof: Theory and Practice of the European Covnvention on Human Rights..., s. 685.

${ }^{50}$ S. Trechsel: Human Rights and Criminal Proceedings. New York 2005, p. 360. 
zaskarżenia nie może abstrahować od trybu, w jakim nastąpiło ustalenie winy. Korelatywne z prawnomiędzynarodowym standardem wydaje się być jednak wyłączenie prawa do spowodowania kontroli odwoławczej orzeczenia $\mathrm{w}$ przedmiocie winy tylko $\mathrm{w}$ tych przypadkach, w których ta nie była przedmiotem kontradyktoryjnego sporu sądowego ${ }^{51}$. By uniknąć dowolności w zakresie ustalania niespornych rozstrzygnięć $\mathrm{w}$ zakresie winy, skalibrowanie zakresu rozstrzygnięć nieobjętych kontrolą odwoławczą musi korelować z formalnym wyłączeniem kontradyktoryjnego sporu sądowego, zachowanie prawnomiędzynarodowego wzorca dwuinstancyjnego postępowania wymaga więc powiązania ograniczeń zakresu kontroli odwoławczej z przypadkami ustalenia winy w trybach szczególnych, opartych o konsens pomiędzy oskarżycielem i oskarżonym zaakceptowanym następnie przez sąd ${ }^{52}$. Skazanie na podstawie „wytargowanego" przyznania się do winy może uzasadniać także wyłączenie prawa do apelacji w zakresie obu elementów objętych prawnomiędzynarodowym standardem kontroli ${ }^{53}$. Akceptacja ugodowego ustalenia winy i kary może być bowiem odczytana nie tylko jako rezygnacja z prawa do merytorycznego zbadania zarzutów, ale także jako zrzeczenie się prawa do zwykłej kontroli $\mathrm{w}$ drodze apelacji ${ }^{54}$. Oskarżony nie ma obowiązku korzystania ze zwyczajnego środka odwoławczego, prawo zaskarżenia orzeczenia do sądu drugiej instancji jest zatem zbywalne. Warunkiem musi być rzetelna ocena treści porozumienia i uczciwej metody jego wypracowania poprzedzająca zatwierdzenie konsensusu przez sąd oraz zgoda na szczególne warunki skazania, wyrażona przez oskarżonego w sposób autentycznie dobrowolny i z pełną świadomością stanu faktycznego oraz implikowanych przez nią konsekwencji prawnych; rezygnacja nie może być więc

${ }^{51}$ Decyzja Komisji z dnia 9 września 1992 r. w sprawie Nielsen p. Danii (skarga nr 19028/91); decyzja Komisji z dnia 30 listopada 1994 r. w sprawie Jakobsen p. Danii (skarga nr 22015/93). W obu sprawach za niesprzeczne ze standardem strasburskim uznano regulacje redukujące dopuszczalność zaskarżenia orzeczeń skazujących za przestępstwo w trybie tzw. gilty plea wyłącznie do części odnoszącej się wymiaru kary.

52 P. Hofmański. W: Konwencja o Ochronie Praw Człowieka i Podstawowych Wolności. Komentarz do art. 19-59 oraz do Protokołów dodatkowych. T. II..., s. 635.

${ }_{53}^{3}$ M.A. Nowicki: Wokót Konwencji Europejskiej. Komentarz do Europejskiej Konwencji Praw Człowieka..., s. 920. Przeciwnego zdania jest P. Hofmański, który przyjmuje, że samo przyznanie się do winy nie powinno być odczytywane jako rezygnacja z prawa do zaskarżenia wyroku. Zob. P. HofMAŃsKI. W: Konwencja o Ochronie Praw Człowieka i Podstawowych Wolności. Komentarz do art. 19-59 oraz do Protokołów dodatkowych. T. II..., s. 632.

${ }^{54} \mathrm{~W}$ orzecznictwie strasburskim przyjmuje się, że istnieje możliwość zrzeczenia się przez zainteresowanego prawa do rzetelnego procesu. Zob. wyrok ETPC z dnia 30 listopada 2001 r. w sprawie Kwiatkowska p. Włochom (skarga nr 52868/99); wyrok ETPC w sprawie Hermi p. Włochom (skarga nr 18114/02); wyrok ETPC z dnia 9 czerwca 2009 r. w sprawie Strzałkowski p. Polsce (skarga nr 31509/02). 
rezultatem przymusu czy też fałszywych obietnic ze strony oskarżyciela ${ }^{55}$, nie powinna także korelować $\mathrm{z}$ istotnym interesem publicznym ${ }^{56}$.

\section{Konstytucyjny wzorzec zaskarżalności orzeczeń}

Standard zaskarżalności orzeczeń ukonstytuowany na poziomie konstytucyjnym jest znacznie szerszy niż zespół zabezpieczeń międzynarodowych, art. 78 Konstytucji RP statuuje bowiem uniwersalną zasadę kontroli ogółu orzeczeń i decyzji wydanych w pierwszej instancji, tj. zarówno $\mathrm{w}$ postępowaniu sądowym, administracyjnym ${ }^{57}$, jak i dyscyplinarnym ${ }^{58}$, a w procesie karnym także orzeczeń i decyzji wydanych w postępowaniu przygotowawczym ${ }^{59}$. Uniwersalna zasada kontroli gwarantuje prawo do zaskarżenia pierwszoinstancyjnych rozstrzygnięć każdej stronie postępowania - dyferencjację uprawnień w zakresie kwestionowania należałoby bowiem uznać za naruszenie zasady równości wobec prawa ${ }^{60}$. Tę natomiast najczęściej definiuje się jako nakaz nadawania takich treści unormowaniom prawnym, które w jednakowy sposób będą kształtowały sytuację prawną podmiotów należących do tej samej kategorii istotnej ${ }^{61}$, zaś ewentualne różnicowanie podmiotów o tej samej cesze musi być posunięciem racjonalnie uzasadnionym, służącym zaspokojeniu interesu na tyle istotnego, by równoważył szkody powstałe wskutek wprowadzenia

${ }^{55}$ Wyrok ETPC z dnia 27 lutego 1980 r. w sprawie Deweer p. Belgii (skarga nr 6903/75); wyrok ETPC z dnia 29 kwietnia 2014 r. w sprawie Nastsvlishvili i Togonidze p. Gruzji (skarga nr 9043/05).

${ }^{56}$ Wyrok ETPC z dnia 17 września 2009 r. w sprawie Scoppola p. Włochom (skarga nr 10249/03); wyrok ETPC z dnia 23 listopada 1993 r. w sprawie Poitrimol p. Francji (skarga nr 14032/88); wyrok ETPC w sprawie Hermi p. Włochom (skarga nr 18114/02)

${ }^{57}$ J. Boć. W: Konstytucje Rzeczpospolitej Polskiej oraz Komentarz do Konstytucji RP z 1997 r. Red. IDEM. Wrocław 1998, s. 141; S. STEINBORN: Ograniczenia zaskarżalności wyroku wydanego $w$ I instancji jako środek uproszczenia procesu karnego $w$ świetle prawa do dwuinstancyjnego postępowania (uwag de lege lata i de lege ferenda). W: Gdańskie Studia Prawnicze. Prawa człowieka..., s. 375; P. Winczorek: Prawo konstytucyjne Rzeczpospolitej Polskiej. Warszawa 2003, s. 96; IDEM: Komentarz do Konstytucji Rzeczpospolitej Polskiej $z$ dnia 2 kwietnia 1997 r. Warszawa 2000, s. 101.

${ }^{58}$ Wyrok TK z dnia 7 marca 1994 r., K. 7/93, OTK 1994, cz. 1, s. 11; wyrok TK z dnia 11 kwietnia 1995 r., K. 112/94, OTK 1995, cz. I, s. 137a; wyrok TK z dnia 8 grudnia 1998 r., K. 41/07, OTK ZU 1998, z. 7, poz. 117.

${ }^{59}$ Wyrok TK z dnia 2 kwietnia 2001 r., SK 10/00, OTK 2001, z. 3, poz. 52.

${ }^{60}$ P. WinczoneK: Komentarz do Konstytucji Rzeczpospolitej Polskiej z dnia 2 kwietnia 1997 r., s. 101.

${ }^{61}$ L. Garlicki: Zasada równości $i$ zakaz dyskryminacji $w$ orzecznictwie Trybunatu Konstytucyjnego. W: Obywatel - jego wolności i prawa. Red. B. Oliwia-RadziKowsKa. Warszawa 1998, s. 65; P. WinczoneK: Komentarz do Konstytucji Rzeczypospolitej Polskiej z dnia 2 kwietnia 1997 r..., s. 101. 
wyjątku oraz znajdującym wsparcie w realizacji innych konstytucyjnych wartości i praw ${ }^{62}$. Równość jest ściśle sprzężona ze sprawiedliwością, afiliacje pomiędzy obiema wartościami eksplikował już Arystoteles, podnosząc, że „(...) zarówno człowiek niesprawiedliwy wykracza przeciw słuszności (czyli równości), jak i to, co niesprawiedliwe, jest niesłuszne (czyli nierówne). Jeśli więc to, co niesprawiedliwe, jest nierówne, w takim razie to, co sprawiedliwe, jest równe" ${ }^{63}$. Nie ulega wątpliwości, że z perspektywy prawa do zaskarżenia orzeczenia strony postępowania są pomiotami równymi, równość dwóch lub większej liczby obiektów oznacza bowiem ich przynależność do co najmniej jednej tej samej klasy wyróżnionej ze względu na określoną cechę, relewantnym kryterium klasyfikującym obie strony procesu do tej samej klasy stanowi możliwe jednakowe naruszenie ich praw i interesów procesowych błędami, omyłkami i uchybieniami popełnionymi przez organ pierwszoinstancyjny. Konstytucyjnie wyeksplikowana ogólna zasada kontroli przewiduje zaskarżalność orzeczeń wydawanych przez pierwszoinstancyjne sądy oraz organy pozasądowe, ponieważ zaś zaskarżenie stanowi pewną kategorię ogólną, z konstytucyjnym wzorcem koresponduje zaskarżalność pierwszoinstancyjnych orzeczeń i decyzji ogółem, tzw. środków zaskarżenia, umożliwiających podmiotowi doznającemu niekorzystnych skutków wygenerowanych przez wydane orzeczenie podjęcie akcji kontestacyjnej przeciwko szkodliwej dla niego decyzji ${ }^{64}$. Prawo do zaskarżenia pierwszoinstancyjnego rozstrzygnięcia może być więc realizowane za pomocą rozmaitych środków prawnych, posiadających wspólną cechę, tj. umożliwienie stronie, poprzez ich wniesienie, weryfikacji podjętego w pierwszej instancji orzeczenia bądź decyzji ${ }^{65}$. W art. 176 ust. 1 Konstytucji, umieszczonym w rozdziale VIII „Sądy i Trybunały”, tę uniwersalną zasadę kontroli rozwinięto, wykształ-

${ }^{62}$ Zob. wyrok TK z dnia 12 grudnia 1994 r., OTK 1994, cz. II, poz. 141; wyrok TK z dnia 23 października 1995 r., K 4/95, OTK 1995, cz. II, poz. 93; orzeczenie TK z dnia 3 września 1996 r., K 10/96, OTK ZU 1996, poz. 281; wyrok WSA w Warszawie z dnia 9 listopada 2005 r., III SA/Wa 2426/05, LEX nr 198985.

${ }^{63}$ Arystoteles: Etyka nikomachejska. Tłum. D. GromsKa. W: Arystoteles: Dzieła wszystkie. T. V. Warszawa 2002, księga V, 1131 a, s. 173.

${ }^{64} \mathrm{~W}$ literaturze procesu karnego środki zaskarżenia określa się jako wnioski zainteresowanego podmiotu zmierzające do wywołania kontroli ściśle procesowej, tj. kontroli uruchamianej wskutek skargi uprawnionego podmiotu, której przedmiotem są decyzje procesowe, a jej celem jest usunięcie nieprawidłowości kontrolowanych decyzji. Zob. M. CIEŚLAK: Polska procedura karna. Podstawowe zatożenia teoretyczne. W: IDEM: Dzieła wybrane. T. II..., s. 304. Nieco innym nazewnictwem posługuje się M. Lipczyńska. Autorka ogół środków przeciwko określonym przedmiotom kontroli, w szczególności czynnościom procesowym, określa bowiem jako środki kontroli. Zob. M. LIPCZYŃsKa: Model postępowania kontrolnego w k.p.k. z 1969 r. PiP 1971, z. 2, s. 298 i nast.

${ }^{65}$ Wyrok TK z dnia 3 lipca 2002 r., SK 31/01, OTK-A 2002, z. 4, poz. 49. 
cając w sprawach w całości objętych kognicją sądownictwa zasadę co najmniej dwuinstancyjnego postępowania. Przepis o dwuinstancyjnym postępowaniu staje się komponentem prawa do sądu, ergo zawiera pierwiastek gwarancyjny w postaci rękojmi zaskarżalności orzeczeń w sprawach objętych prawem do sądu środkiem zaskarżenia uruchamiającym nie jakąkolwiek kontrolę orzeczenia i decyzji, a kontrolę spełniającą dalej idące wymogi, tj. kontrolę cechującą się instancyjnością ${ }^{66}$. Konstytucyjny wzorzec zaskarżalności orzeczeń ma bardzo szeroki zakres, na poziomie konstytucyjnym uprawnienie do skorzystania ze zwyczajnego środka odwoławczego zostało ukształtowane jako prawo każdej strony posiadającej legitymację do zakwestionowania wszystkich szkodliwych dla niej rozstrzygnięć sądu - niezależnie od charakteru (cywilnego, karnego czy też administracyjnego) sprawy rozstrzygniętej przez sąd i bez względu na przedmiot kwestionowanych orzeczeń. Usytuowanie przepisu o co najmniej dwuinstancyjnym postępowaniu w przepisach dotyczących ustroju sądów nie pozwala kategoryzować go jako dekretacji podmiotowego prawa jednostki do dwuinstancyjnego postępowania, ergo prawo do zaskarżenia orzeczeń sądowych nie musi być realizowane poprzez środki prawne uruchamiające kontrolę instancyjną (tok instancji), a więc poprzez środki odwoławcze o charakterze dewolutywnym ${ }^{67}$. Prawo do zaskarżenia

${ }^{66}$ Pogląd o podwójnym ustrojowo-gwarancyjnym charakterze przepisu art. 176 ust. 1 Konstytucji RP jest mocno ugruntowany w orzecznictwie konstytucyjnym oraz w doktrynie prawa. Stanowisko o podwójnym znaczeniu przepisu o dwuinstancyjnym postępowaniu Trybunał Konstytucyjny wyeksplikował w następujących judykatach: wyrok z dnia 12 stycznia 2010 r., SK 2/09, OTK - A 2009, nr 1, poz. 1; wyrok z dnia 13 lipca 2009 r., SK $46 / 08$, OTK - A 2009, nr 7, poz. 109. Na gruncie doktryny prawa cywilnego pogląd o podwójnym charakterze art. 176 ust. 1 Konstytucji wyraziła M. Michalska-Marciniak. Zob. M. MichalsKa-MarciniaK: Zasada instancyjności w postępowaniu cywilnym. Warszawa 2012, s. 187. W dziedzinie prawa karnego procesowego identyczny pogląd sformułowali G. Artymiak, K. Marszał, S. Steinborn, P. Wiliński. Zob. G. ARTYMiAK: „Instancja pozioma” jako jedna z propozycji usprawnienia postępowania karnego - uwagi de lege lata i de lege ferenda. W: Funkcje Procesu Karnego. Ksiega jubileuszowa Profesora Janusza Tylmana. Red. T. GrzegorczyK. Warszawa 2011, s. 592; K. Marszat: Zaskarżalność decyzji wydanych $w$ procesie karnym. PS 2007, z. 3, s. 63; IDEM: Konstytucyjna zasada zaskarżalności decyzji $w$ procesie karnym. „Wojskowy Przegląd Prawniczy” 2007, z. 3, s. 10 i nast.; S. STEINBORN: Ograniczenie zaskarżalności wyroku wydanego w I instancji jako środek uproszczenia procesu karnego $w$ świetle prawa do dwuinstancyjnego postępowania (uwagi de lege lata i de lege ferenda). W: Gdańskie Studia Prawnicze. Prawa człowieka..., s. 375 i nast.; P. Wiliński: Proces karny w świetle Konstytucji..., s. 154.

${ }^{67}$ Przeciwnego zdania jest Trybunał Konstytucyjny, który zakłada, że art. 78 Konstytucji RP gwarantuje jednostce, której statusu prawnego dana sprawa dotyczy, prawo do zaskarżenia orzeczeń i decyzji do organu wyższej instancji w celu sprawdzenia (skontrolowania) prawidłowości orzeczenia. Zdaniem Trybunału Konstytucyjnego użyte w art. 78 Konstytucji RP sformułowanie „orzeczenia i decyzje wydane w I instancji” sugeruje, że chodzi o środki prawne uruchamiające kontrolę instancyjną. Nie wydaje się jednak 
pierwszoinstancyjnego orzeczenia sądu może być urzeczywistnione za pomocą środków prawnych nieprzesuwających rozstrzygnięcia sprawy do drugiej instancji, tylko implikujących ponowne jej rozpatrzenie przez organ wydający zaskarżone orzeczenie lub decyzję (np. niedewolutywne sprzeciwy kasujące ex lege zaskarżone orzeczenie i powodujące ponownie rozpoznanie sprawy $\mathrm{w}$ sądzie in meriti) ${ }^{68}$. Konstytucyjne zabezpieczenia zaskarżalności orzeczeń i decyzji wydanych w pierwszej instancji pozbawione są absolutnego charakteru, uniwersalną zasadę kontroli wyeksplikowano, tworząc jednocześnie delegację do określenia trybu zaskarżenia oraz zakresu wyjątków na poziomie ustawodawstwa zwykłego (art. 78 zd. 2 Konstytucji RP). Konstytucyjna delegacja do ustawowego ukształtowania wyjątków od zasady zaskarżalności pierwszoinstancyjnych rozstrzygnięć nie zawiera wskazań co przedmiotowego zakresu ograniczeń, ustawowy porządek prawny może więc całkowicie wyłączyć zaskarżalność niektórych pierwszoinstancyjnych orzeczeń i decyzji; na poziomie ustawodawstwa zwykłego dopuszczalne jest także ograniczenie katalogu przyczyn stanowiących podstawę zakwestionowania orzeczenia objętego gwarancją zaskarżalności. Swoboda ustawodawcy zwykłego do kształtowania kontroli pierwszoinstancyjnych rozstrzygnięć nie jest nieograniczona, ekscepcje od uniwersalnej reguły kontroli ogółu orzeczeń i decyzji nie mogą bowiem całkowicie wyłączyć zaskarżalności wyroku wydanego

zasadne, by zasadę kontroli instancyjnej wywodzić z przepisu, który nie zawiera żadnych odniesień do przebiegu postępowania przed dwoma hierarchicznie nierównorzędnymi sądami, stanowiącego immanentną cechę zasady dwuinstancyjnego postępowania. Użycie sformułowania „instancja” nastąpiło w kontekście określania poziomu, na jakim w strukturze sądownictwa ulokowany jest sąd podejmujący zaskarżalna decyzję. Rację ma też S. Steinborn wskazujący, że wywodzenie zasady dwuinstancyjnego postępowania $\mathrm{z}$ art. 78 Konstytucji RP prowadzi do uznania przepisu art. 176 ust. 1 Konstytucji RP za superfluum. Zob. wyrok TK z dnia 15 maja 2000 r., SK 29/99, OTK 2000, z. 4, poz. 110; wyrok TK z dnia 11 czerwca 2002 r., SK 5/02, OTK-A 2002, z. 4, poz. 41; wyrok TK z dnia 12 czerwca 2002 r., P 13/01, OTK-A 2002, z. 4, poz. 42. O krytyce stanowiska Trybunału Konstytucyjnego zob. S. STEINBORN: Ograniczenia zaskarżalności wyroku wydanego $w$ I instancji jako środek uproszczenia procesu karnego $w$ świetle prawa do dwuinstancyjnego postępowania (uwag de lege lata $i$ de lege ferenda). W: Gdańskie Studia Prawnicze. Prawa człowieka..., s. 375. O nadregulacji w prawie zob. M. KŁodawski: Superfluum i nadwyżki znaczeniowe jako przykłady redundancji tekstu prawnego. „Archiwum Filozofii Prawa i Filozofii Społecznej” 2013, z. 2, s. 39; A. MaŁocha-Krupa: Słowa w lustrze. Pleonazm semantyka - pragmatyka. Wrocław 2003, s. 19.

${ }^{68}$ W swoim orzecznictwie Trybunał Konstytucyjny konsekwentnie kategoryzuje niedewolutywne środki zaskarżenia skutkujące ponownym rozpoznaniem sprawy przez sąd wydający zaskarżone orzeczenie jako wyjątki od zasady dwuinstancyjnego postępowania dopuszczalne na podstawie art. 78 zd. 2 Konstytucji RP, a nie inny sposób realizacji prawa do zaskarżenia orzeczenia wydanego w I instancji. Zob. wyrok TK z dnia 16 listopada 1999 r., SK 11/99, OTK 1999, z. 7, poz. 158; wyrok TK z dnia 12 czerwca 2002 r., P 13/01, OTK-A 2002, z. 4, poz. 42. 
w pierwszej instancji, derogować zaskarżalność tylko niektórych rodzajów wyroków odwołując się do ich treści ${ }^{69}$ czy też przekształcać uprawnienia do zakwestionowania pierwszoinstancyjnych rozstrzygnięć w instytucję fikcyjną ${ }^{70}$. Ponadto powinny być dyktowane wyłącznie szczególnymi okolicznościami usprawiedliwiającymi pozbawienie strony postępowania środka zaskarżenia ${ }^{71}$.

\section{Wyłączenie instancyjnej kontroli faktów sprawy stanowiących podstawę wyroków kontraktowych w perspektywie międzynarodowej}

Z perspektywy prawnomiędzynarodowych i konstytucyjnych gwarancji dwuinstancyjnego postępowania derogacja instancyjnego kontrolowania errores facti in iudicando na poziomie ustawodawstwa zwykłego nie budzi wątpliwości w sytuacji, gdy rozstrzygnięcie w przedmiocie winy i kary stanowiło przedmiot kontraktu procesowego. Konwencyjny wzorzec w zakresie prawa do skorzystania ze zwyczajnego środka odwoławczego dopuszcza bowiem ekscepcję od prawa spowodowania kontroli instancyjnej orzeczenia $\mathrm{w}$ przedmiocie winy, a nawet jednoczesne wyłączenie rozstrzygnięcia w kwestii winy i kary wówczas, gdy jeden lub oba elementy orzeczenia nie stanowiły przedmiotu kontradyktoryjnego sporu sądowego. Korelatywne z prawnomiędzynarodowym standardem zaskarżalności orzeczeń są więc ukonstytuowane na poziomie polskiego ustawodawstwa ograniczenia zaskarżalności wyroku kontraktowego, polegające na zakazie formułowania w apelacji atakującej zarzutu określonego $\mathrm{w}$ art. 438 pkt 3 k.p.k., tj. subiektywnego twierdzenia o rzekomych błędach popełnionych przez pierwszoinstancyjnego decydenta w zakresie

${ }^{69}$ S. STEINBoRn: Ograniczenia zaskarżalności wyroku wydanego w I instancji jako środek uproszczenia procesu karnego w świetle prawa do dwuinstancyjnego postępowania (uwag de lege lata i de lege ferenda). W: Gdańskie Studia Prawnicze. Prawa człowieka..., s. 380.

${ }^{70} \mathrm{~W}$ wyroku z dnia 12 marca 2002 r., P 9/01, OTK ZU 2002, z. 2A, poz. 14, Trybunał Konstytucyjny uznał, że prawo strony do rozpatrzenia sprawy przez sąd drugiej instancji może być naruszone zarówno bezpośrednio (poprzez wyłączenie możliwości wniesienia apelacji), jak i pośrednio (poprzez ustanowienie takich formalnych warunków wniesienia apelacji, które czynność tę czyniłyby nadmiernie utrudnioną. Podobnie Trybunał Konstytucyjny wypowiedział się w wyroku z dnia 12 września 2006 r., SK 21/95, OTK ZU 2006, z. 2A, poz. 103. Z kolei w wyroku z dnia 12 czerwca 2002 r., P 13/01, OTK-A 2002, z. 4, poz. 42 Trybunał Konstytucyjny stwierdził, że z punktu widzenia regulacji zawartych w Konstytucji środek zaskarżenia powinien być skuteczny w tym sensie, iż powinien umożliwiać merytoryczne rozstrzygnięcie sprawy w postępowaniu odwoławczym. Na konieczność zapewnienia realnego prawa spowodowania kontroli pierwszoinstancyjnego rozstrzygnięcia Trybunał Konstytucyjny zwrócił też uwagę w wyroku z dnia 13 stycznia 2004 r., SK 10/03, OTK ZU 2004, z. 2A, poz. 2.

${ }^{71}$ Wyrok TK z dnia 12 czerwca 2002 r., P 13/01, OTK-A 2002, z. 4, poz. 42. 
rekonstrukcji tkwiących u podstaw wynegocjowanego wyroku wydanego we wszystkich trybach konsensualnych - tj. uproszczonym, samoistnym albo konsensualnym trybie uproszczonym (art. $335 \$ 1$ k.p.k.) - w pełnym lub zwykłym trybie skazania bez rozprawy (art. 335 \$2 k.p.k.) w ramach konstrukcji niekiedy kwalifikowanej jako inna forma skazania bez rozprawy ${ }^{72}$, innym zaś razem jako instytucja hybrydalna, stanowiąca wypadkową konsensualnego skazania na posiedzeniu bez rozprawy i dobrowolnego poddania się karze ${ }^{73}$, w istocie zaś będąca formą poszerzenia zakresu stosowalności instytucji dobrowolnego poddania się karze (art. 338a k.p.k.) ${ }^{74}$ - oraz w ramach tradycyjnego modelu instytucji dobrowolnego poddania się karze na rozprawie (art. 387 k.p.k.). W perspektywie teoretycznoprawnej tryby konsensualne można kategoryzować jako pewien sposób rozwiązania konfliktu pomiędzy prawami jednostki (oskarżonego) i dobrem wspólnym naruszonym w wyniku popełnienia przestępstwa przez jednostkę. Ujmując ten konflikt w nurcie filozofii poli-

${ }^{72}$ K. DĄBKIEwicz: Merytoryczne orzekanie sądu pierwszej instancji poza rozprawa głównq. „Kwartalnik Sądowy Apelacji Gdańskiej” 2016, z. 1, s. 109; B. WójсıскA: Kilka uwag na temat zmian dotyczacych sytuacji pokrzywdzonego $w$ procesie karnym. W: Polski proces karny i materialne prawo karne $w$ świetle nowelizacji z 2013 r. Księga jubileuszowa dedykowana Profesorowi Januszowi Tylmanowi z okazji Jego 90. urodzin. Red. T. GrzegorCzYK, J. IzYDORCZYK, R. OlszewsKI. Warszawa 2014, s. 248; IDEM: Sytuacja pokrzywdzonego w procesie karnym po zmianach $w$ prawie karnym $w$ latach 2015-2016 (wybrane zagadnienia). W: Verba volant, scripta manent. Proces karny, prawo karne skarbowe i prawo wykroczeń po zmianach z lat 2015-2016. Księga pamiątkowa poświęcona Profesor Monice Zbrojewskiej. Red. T. GrzegorczyK, R. Olszewski. Warszawa 2017, s. 516.

${ }^{73}$ R. KOPER: O nowej formie konsensualizmu w procesie karnym (art. 338 a i art. 343 a k.p.k.), Pal. 2014, z. 7-8, s. 9; IDEM: Brak watpliwości dotyczacych okoliczności popetnienia przestępstwa $i$ winy jako warunek stosowania regulacji konsensualnych $w$ procesie karnym. W: Verba volant, scripta manent. Proces karny..., s. 162 i nast.

${ }^{74}$ B. BAchursKa: Dobrowolne poddanie się odpowiedzialności karnej z art. 387 k.p.k. $w$ świetle nowelizacji kodeksu postępowania karnego z dnia 27 września 2013 r. „Ius et Administratio" 2013, z. 4, s. 8; A. BuŁAT: Skazanie w trybach konsensualnych - sposób na przyspieszenie postępowania karnego czy zagrożenie dla interesu oskarżonego?. W: Verba volant, scripta manent. Proces karny..., s. 870; T. GrZEgorczYK: Kodeks postępowania karnego. T. I: Komentarz do art. 1-467. Warszawa 2014, s. 1187; IdEM: Podstawowe kierunki projektowanych zmian procedury karnej. PiP 2012, z. 11, s. 22; W. JAsIŃskI: Porozumienia procesowe $w$ znowelizowanym kodeksie postępowania karnego. Prok. i Pr. 2014, z. 10, s. 20; P. KRusZYŃsKI, M. ZBRoJewsKa: Nowy model postępowania karnego ukształtowany nowela do k.p.k. z 27 września 2013 r. Pal. 2014, z. 1-2, s. 64; J. ŁAWNICKI: Konsensualizm procesowy po nowelizacji Kodeksu postępowania karnego. „Kwartalnik Krajowej Szkoły Sądownictwa i Prokuratury” 2014, z. 3, s. 96; L.K. PAPRZYCKI: Rzetelność trybów konsensualnych po nowelizacji 2013-2015. W: Wokót gwarancji współczesnego procesu karnego. Księga jubileuszowa Prof. P. Kruszyńskiego. Red. M. Rogacka-Rzewnicka, H. GajewsKa-KraczKowsKa, B.T. BieŃKowsKa. Warszawa 2015, s. 365; B.J. STEFAŃSKA: Skazanie na posiedzeniu bez przeprowadzania postępowania dowodowego. W: Verba volant, scripta manent. Proces karny..., s. 790 . 
tycznej, jego modelowe rozwiązanie jest sprzężone z dwoma odmiennymi doktrynami, tj. liberalizmem i komunitaryzmem.

Fundament filozofii liberalnej stanowi priorytet praw i wolności jednostkowych ujmowanych negatywnie (,wolność od”) nad dobrem wspólnym (in dubio pro libertate) oraz nad takimi wartościami perfekcjonistycznymi jak zaspokojenie pragnień czy też przyjemności, bądź interesów jednostki ${ }^{75}$. Konsensualizm liberalny może więc akceptować porozumienia procesowe modyfikujące na korzyść oskarżonego reguły wymiaru kary przewidziane w prawie karnym materialnym, mimo że tego typu kontrakty oznaczają deprecjację dobra wspólnego i praw pokrzywdzonego. W trybach konsensualnych skonstruowanych według założeń filozofii liberalnej jakiekolwiek ograniczenia dotyczące zaskarżalności wyroku kontraktowego są nie do pomyślenia, oznaczają bowiem naruszenie prawa do jak najszerszego zakresu wolności, dającej każdemu człowiekowi możliwość działania stosownie do własnych decyzji i preferencji. Tymczasem w systemie aksjologicznym liberalizmu wolność jest wartością autoteliczną i absolutną, jak twierdził F.A. Hayek - musi być więc przyjęta za najwyższe dobro niezależnie od swoich faktycznych konsekwencji w konkretnych przypadkach. „Musi być ona zaakceptowana jako wartość sama w sobie, jako zasada, która winna być respektowana bez rozstrząsania, czy konsekwencje w każdym przypadku będą dobroczynne"76.

Konstrukcja trybów konsensualnych nie powinna być ani radykalnie liberalna, ani fundamentalnie komunitarna, rozstrzygnięcie konfliktu prawami jednostki i dobrem wspólnym powinno bowiem zakładać „(...) staranny i rozważny proces ważenia argumentów pro i contra"77. Konkretne rozwiązania wymagają starannego wyważenia obu zantagonizowanych dóbr, tak by koncepcja porozumień karnoprocesowych nie opierała się na apriorycznym założeniu przewagi jednostki i jednoczesnej deprecjacji dobra wspólnego ${ }^{78}$. Bilans wartości liberalnych i komunitar-

75 J. Rawls: Liberalizm polityczny. Tłum. A. Romaniuk. Warszawa 1998, s. 396; IDEM: Teoria sprawiedliwości. Tłum. M. PAnufnik, J. Pasek, A. Romaniuk. Warszawa 1994, s. 39 i nast.

${ }^{76}$ F.A. HayeK: Konstytucja wolności. Tłum. M. Kuniński. Warszawa 2006, s. 31. O założeniach liberalizmu i neoliberalizmu zob. Z. RAU: Liberalizm. Zarys myśli politycznej XIX i XX wieku. Warszawa 2000, s. 125; W. SADURSKI: Neoliberalny system wartości politycznych. Warszawa 1980, s. 33 i nast.

${ }_{77}$ L. Morawski: Prawa jednostki a dobro wspólne (Liberalizm versus komunitaryzm). PiP 1998, z. 11, s. 242.

${ }^{78}$ L. Morawski: Liberalizm, komunitaryzm i republikanizm. W: L. Morawski: Filozofia prawa. Warszawa 2014, s. 113 i nast.; IDEM: Prawa jednostki a dobro wspólne..., s. 26. O zagrożeniach dla praw pokrzywdzonego związanych z zawarciem porozumienia w trybie konsensualnym zob. również M. McConville: The victims of plea bargaininng. W: Zasady procesu karnego wobec wyzwań wspótczesności. Księga ku czci Profesora Stanisława 
nych nie wyklucza ograniczenia czy też ustalenia zakresu zastosowalności zasady in dubio pro libertate, na gruncie procesu karnego staranna rekapitulacja założeń filozofii liberalnej i komunitarnej dopuszcza pewne więc limitacje prawa jednostki do spowodowania kontroli instancyjnej wyroków konsensualnych pod warunkiem, że będą one zgodne z koniecznością prawnokarnej ochrony dobra wspólnego zaburzonego lub zagrożonego wskutek realizacji przestępstwa. Prawo jednostki do spowodowania wieloaspektowej kontroli odwoławczej może być zatem ograniczone, ze względu na rachunek społecznych interesów wymagających szybkiego przywrócenia homeostazy społecznej, korzyści w zakresie ekonomii procesowej oraz sprawność funkcjonowania instytucji państwowych powoduje, że zakaz podnoszenia zarzutu errores facti in iudicando $\mathrm{w}$ apelacji od wyroków kontraktowych może być uznany za rozwiązanie sprzyjające zaspokojeniu tak rozumianych wartości prowspólnotowych.

Zakaz podnoszenia zarzutu errores facti in iudicando w apelacji od wyroków objętych porozumieniem karnoprocesowym dotyczy partycypantów porozumienia oraz pokrzywdzonego występującego w roli oskarżyciela posiłkowego, mimo że pokrzywdzony formalnie nie jest stroną kontraktu karnego; partycypantami porozumienia pozostają bowiem organy procesowe oraz oskarżony. Symetryczne ograniczenie prawa do podnoszenia $\mathrm{w}$ apelacji od wyroku kontraktowego zarzutu errores facti in iudicando realizuje zasadę równości wobec prawa; w ten sposób zostaje zrównana sytuacja prawa wszystkich podmiotów zainteresowanych treścią porozumienia. Zarówno bowiem pokrzywdzony, jak i oskarżony, odpowiednio niesprzeciwiający się (art. $343 \$ 2,387$ \$2 in fine k.p.k.) albo partycypujący w negocjowaniu wyroku kontraktowego (art. 335 §1-2, 338 a oraz 387 § 1 k.p.k.) opartego na ustaleniach faktycznych, z założenia niebudzących wątpliwości, z pewnością przynależą do tej samej kategorii istotnej wykształconej ze względu na aprobatywny stosunek do rekonstrukcji dokonanych przez pierwszoinstancyjnego arbitra. Derogacja instancyjnego kontrolowania błędów odtworzeniowych wyklucza jakąkolwiek kontrolę stanu faktycznego co do zaszłości objętej porozumieniem. Malgré lui stanowisko orzecznictwa strasburskiego, dopuszczające zbywalność prawa do instancyjnej kontroli orzeczeń, nie implikuje pewności co do koherencji pomiędzy rezygnacją z kontrolowania rekonstrukcji tkwiących u pod-

Waltosia..., s. 524 i nast.; R. КмІЕсік: O dwu koncepcjach dalszego rozwoju procedury karnej (Uwagi z zwiazku z tzw. konsensualizmem procesowym). W: Aktualne problemy prawa i procesu karnego. Księga ofiarowana Profesorowi Janowi Grajewskiemu. Red. M. PŁachta. GSP 2003, t. XI, s. 103; IDEM: Pokrzywdzony jako oskarżyciel a „sprawiedliwość naprawcza” - rys historyczny z perspektywy wspótczesnej. AUMCS 2009/2010, sectio G, vol. LVI/LVII, s. 94 i nast.; J. ZAGRoDNIK: Model interakcji postępowania przygotowawczego oraz postępowania głównego w procesie karnym. Warszawa 2013, s. 148. 
staw wyroku kontraktowego a prawnomiędzynarodowym standardem zaskarżalności orzeczeń. W literaturze zakwestionowano założenie, zgodnie z którym akceptacja porozumienia procesowego znajdującego odzwierciedlenie w zapadającym wyroku wystarcza do przyjęcia, że tym samym strony rezygnują ze zbadania przez sąd odwoławczy okoliczności faktycznych leżących u podstaw zawartego porozumienia. Nie da się bowiem wykluczyć sytuacji, w której sąd pierwszej instancji błędnie zanalizował materiał dowodowy, przyjmując spełnienie kryteriów przemawiających za konsensualnym zakończeniem postępowania ${ }^{79}$. W świetle obowiązującego stanu prawnego stanowisko negujące możliwość traktowania akceptacji porozumienia procesowego za równoznaczne ze zrzeczeniem się prawa do eksplikowania w skardze odwoławczej zarzutu błędu rekonstrukcyjnego nie wydaje się jednak zasadne. Ustawodawca tak ukształtował przepisy nakierowane na przygotowanie strony do niepodnoszenia w apelacji zarzutów kwestionujących rekonstrukcję prawnie relewantnej zaszłości, że zgoda oskarżonego na rezygnację z prawa do podnoszenia zarzutu błędu odtworzeniowego następuje z pełną świadomością konsekwencji prawnych implikowanych w zakresie postępowania odwoławczego. Beneficjent porozumienia karnoprocesowego jest bowiem konsekwentnie przysposabiany do ograniczonego charakteru kontroli wyroku kontraktowego, zaś zaniechanie działań uprzedzających o wyłączeniu wieloaspektowej kontroli konsensualnego wyroku, nie mogąc wygenerować ujemnych dla oskarżonego skutków (art. 16 §1 k.p.k.), uprawnia oskarżonego do eksplikacji zarzutu kwestionującego rekonstrukcję czynu przestępnego.

Partycypant porozumienia obejmującego wydanie na posiedzeniu wyroku skazującego i orzeczenie uzgodnionych z oskarżonym kar lub innych środków przewidzianych za zarzucany mu występek oraz zasądzenia od niego kosztów na ustalonych zasadach jest aż dwukrotnie, być może więc nawet nadmiernie, informowany o zakazie podnoszenia w apelacji zarzutów eksplikujących błędy. Po raz pierwszy potencjalny beneficjent kontraktu procesowego jest informowany o ograniczonym zakresie kontroli odwoławczej przez prokuratora już w trakcie negocjowania treści kontraktu na etapie postępowania przygotowawczego (art. 335 §2a k.p.k.), a tę samą informację potencjalny beneficjent wyroku kontraktowego uzyskuje od sądu tuż przed, de nomine po podjęciu decyzji o uwzględnieniu wniosku (art. 434 § 5a k.p.k.), de facto jednak - celem skutecznego uświadomienia go o redukcji zakresu kontroli odwoławczej - jeszcze przed jego

79 W. JAsIŃsKI, M. KuŹMA: Granice zaskarżalności porozumień procesowych. W: Wspótzależność prawa karnego materialnego $i$ procesowego $w$ świetle kodyfikacji karnych z 1997 r. i propozycji ich zmian. Red. Z. ĆWIĄKALsKi, G. ArTyMiaK. Warszawa 2009, s. 328. 
rozpoznaniem ${ }^{80}$. Potencjalnego beneficjenta instytucji dobrowolnego poddania się karze, bez względu na forum wydania wyroku kontraktowego, uprzedza się także o zakazie eksplikowania w apelacji errores facti in iudicando oraz erorres poena najpóźniej przed uwzględnieniem wniosku o wydanie wyroku skazującego i orzeczenie zestawu zaproponowanych środków reakcji karnej, tj. w czasookresie poprzedzającym podjęcie decyzji o zastosowaniu instytucji dobrowolnego poddania się karze (art. 343a §2 in fine $\mathrm{w}$ zw. $\mathrm{z}$ art. 343 k.p.k. oraz art. 387 §1a k.p.k.) ${ }^{81}$. Obowiązki sądu nakierowane na wytworzenie takiej sytuacji informacyjnej, by zawarcie kontraktu następowało w warunkach pełnej świadomości implikowanego nim zakazu podnoszenia zarzutu errores facti in iudicando, pozwalaja przyjąć, że fakt rezygnacji ze zbadania przez sąd odwoławczy okoliczności faktycznych stanowi czynność objętą przynajmniej domniemaniem faktycznym w znaczeniu materialnym. Mimo że pokrzywdzony nie partycypuje w zawarciu kontraktu procesowego, jego sytuacja procesowa została ukształtowana w sposób pozwalający domniemywać akceptację rekonstrukcji leżących u podstaw faktycznych wyroku kontraktowego. De lege lata stanowisko pokrzywdzonego dotyczące treści porozumienia procesowego ma fundamentalne znaczenie dla dopuszczalności jego zawarcia, skazanie we wszystkich trybach konsensualnych jest bowiem uzależnione od braku sprzeciwu pokrzywdzonego. Jednocześnie sytuacja informacyjna pokrzywdzonego jest ukształtowana na tyle dobrze, by przyjąć, że akceptacja rozstrzygnięć wynegocjowanych przez partycypantów kontraktu następuje z pełną świadomością co do deskrypcji czynu w ujęciu procesowym. Pokrzywdzony posiada bowiem wszelkie instrumentarium pozwalające mu na pozyskanie informacji o opisie stanu faktycznego stanowiącego podstawę zarzutu stawianego potencjalnemu partycypantowi porozumienia karnoprocesowego; wiedzę o okolicznościach faktycznych sprawy pokrzywdzony może bowiem uzyskać motu proprio, składając już w stadium przygotowawczym wniosek o dostęp do informacji co do zarzutów stawianych wobec oskarżonego oraz o prawo dostępu do akt sprawy, w tym do przeglądania akt oraz samodzielnego sporządzania z nich odpisów i kopii. Ponadto w razie, gdy szansa na skazanie wyrokiem kontraktowym rysuje się już w postępowaniu przygotowawczym, tj. w razie, gdy treść porozumienia ustalono już w toku postępowania przygotowawczego w negocjacjach pomiędzy prokuratorem i podejrzanym, pokrzywdzony otrzymuje informacje dotyczące rekonstrukcji czynu objętego try-

${ }^{80}$ B. AugustyniaK et al.: Kodeks postępowania karnego. Komentarz do zmian 2016. Red. D. ŚwIECKI. Warszawa 2016, s. 337 i 399.

${ }^{81}$ M. FInGAs: Zakres rozpoznania sprawy przez sad odwoławczy w przypadku zaskarżenia przez tzw. strone prywatna orzeczenia wydanego $w$ trybie konsensualnym. W: Verba volant, scripta manent. Proces karny..., s. 600 i nast. 
bem konsensualnym ex officio. Prezes sądu (przewodniczący wydziału, inny upoważniony sędzia) albo referendarz sądowy jest bowiem zobowiązany do doręczenia ujawnionemu pokrzywdzonemu samodzielnego wniosku o skazanie składanego w konsensualnym trybie uproszczonym oraz odpisu aktu oskarżenia i dołączonego do niego wniosku o skazanie składanych łącznie w pełnym trybie skazania bez rozprawy (art. 338 $\S 1$ b k.p.k.).

Zarówno wniosek o skazanie bez rozprawy, jak i akta oskarżenia powinny zawierać identycznie dane odnoszące się do deskrypcji czynu objętego zarzutem, w konkluzji obu skarg powinno bowiem znaleźć się dokładne określenie inkryminowanego oskarżonemu czynu, wraz ze wskazaniem czasu, miejsca, sposobu i okoliczności jego popełnienia oraz opisem danych dotyczących pokrzywdzonego ${ }^{82}$, a także charakterystyką im-

82 Sąd Najwyższy zwrócił uwagę na konieczność wskazania danych dotyczących pokrzywdzonego w konkluzji aktu oskarżenia ze względu na znaczenie tożsamości pokrzywdzonego dla określenia granic oskarżenia. Zob. postanowienie SN z dnia 11 grudnia 2006 r., II KK 304/06, OSNwSK 2006, z. 1, poz. 2403. Zdaniem Sądu Najwyższego obowiązek określenia danych pokrzywdzonego aktualizuje się także w sprawach, w których zastosowano instytucję świadka incognito. Zakres dopuszczalnej anonimizacji okoliczności umożliwiających identyfikację świadka incognito wyklucza bowiem możliwość nadania takiego statusu pokrzywdzonemu. Zob. uchwała SN z dnia 20 stycznia 1999 r., I KZP 21/98, OSNKW 1999, z. 1-2, poz. 3; wyrok SN z dnia 5 stycznia 2000 r., II KKN 391/99, OSNKW 2000, z. 1-2, poz. 13; Ł. WoźNIAK: Glosa aprobujaca do uchwaty Sądu Najwyższego z dnia 20 stycznia 1999 r., I KZP 21/98. OSP 1999, z. 6, s. 316; B. SzYPROWsKI: Glosa aprobujaca do uchwaty Sadu Najwyższego z dnia 20 stycznia 1999 r., I KZP 21/98. OSP 1999, z. 9, s. 418; B. KolasińsKI, T. KuliKowsKi: Glosa krytyczna do uchwały Sądu Najwyższego z dnia 20 stycznia 1999 r., I KZP 21/98. Prok. i Pr. 2000, z. 4, s. 99; T. GRZEGorczYK: Kodeks postępowania karnego oraz ustawa o świadku koronnym. Komentarz. Warszawa 2008, s. 422; P. HofmańsKi, E. SAdZIK, K. ZgryzeK: Kodeks postępowania karnego. T. I: Komentarz do artykutów 1-296. Red. P. HofmańsKi. Warszawa 2004, s. 856; P. HoFmańsKi: Świadek anonimowy $w$ procesie karnym. Kraków 1998, s. 119; IDEM: Świadek anonimowy w procesie karnym. PPol 1994, z. 2-3, s. 13; P. HоғмAŃsKI, S. ZAвŁOCKI: Świadek anonimowy - niespetnione nadzieje. W: Zasady procesu karnego wobec wyzwań wspótczesności. Księga ku czci Profesora Stanistawa Waltosia..., s. 678; A. KoŁodzIEJCzyK: Pokrzywdzony w charakterze świadka anonimowego. Prok. i Pr. 2007, z. 1, s. 60 i nast.; R. NetczuK: Świadek anonimowy w polskim procesie karnym (zakres przedmiotowy utajnienia a skuteczność ochrony). PPol 2002, z. 1, s. 97; H. Pracki: Instytucja świadka anonimowego w orzecznictwie Europejskiego Trybunatu Praw Człowieka w Strasburgu oraz sądów polskich. Prok. i Pr. 2003, z. 2, s. 7; A. SzKLarczYK: Przedmiotowy zakres utajnienia świadka anonimowego na tle przepisów ustawy nowelizujacej kodeks postępowania karnego z 10 stycznia 2003 r. Probl. Prawa Karnego 2004, z. 25, s. 162 i nast.; S. Waltoś: Dylematy ochrony świadka $w$ procesie karnym. PiP 1995, z. 4, s. 40; J. Tylman: Instytucja świadka incognito. AUL 1997, T. 65, s. 41; IDEM: Dylematy instytucji świadka incognito. W: Wspótczesny polski proces karny. Księga ofiarowana..., s. 76; A. WĄSEK: Świadek anonimowy $w$ rzetelnym procesie karnym. W: Kierunki $i$ stan reformy prawa karnego. Red. T. BojARsKI, E. SKrĘTOWICZ. Lublin 1995, s. 77; P. WiLIŃSKI: Świadek incognito $w$ polskim procesie karnym. Kraków 2003, s. 536. 
plikowanych przez przestępstwo skutków, zwłaszcza wysokości powstałej szkody. Prawo pokrzywdzonego do informacji o opisie czynu zarzucanego oskarżonemu może się urzeczywistnić także poprzez zgłoszenie przez pokrzywdzonego żądania przedstawienia mu przez sąd informacji o zarzutach stawianych oskarżonemu oraz o ich kwalifikacji prawnej. Gwarancja dostępu do informacji dotyczących deskrypcji czynu objętego wnioskiem o konsensualne skazanie może być przez pokrzywdzonego realizowane w każdym momencie sądowego procedowania w trybie kontraktowym.

We wszystkich trybach konsensualnych oraz w sprawach, w których postępowanie kontraktowe może zostać zainicjowane dopiero na rozprawie, pokrzywdzony jest odpowiednio wcześniej informowany o możliwości konsensualnego sfinalizowania postępowania oraz o przysługującym mu uprawnieniu do zablokowania kontraktu pomiędzy oskarżonym i organami procesowymi. We wszystkich sytuacjach, w których rysuje się szansa na skazanie wyrokiem kontraktowym już w postępowaniu przejściowym, tj. w razie, gdy treść porozumienia ustalono w negocjacjach pomiędzy prokuratorem i podejrzanym już $\mathrm{w}$ toku postępowania przygotowawczego albo gdy sprawa jest objęta zakresem zastosowalności instytucji dobrowolnego poddania się karze, pokrzywdzony uzyskuje odpowiednie informacje od oskarżyciela publicznego już w chwili zainicjowania postępowania jurysdykcyjnego (art. 334 § 3 k.p.k.). Pokrzywdzony może także uczestniczyć we wszystkich forach sądowych, w trakcie których dokonuje się konsensualne zamknięcie postępowania.

Uprawnienie pokrzywdzonego ma charakter bezwzględny, jednak obowiązek doręczenia zawiadomienia o ich czasie i miejscu materializuje się dopiero po złożeniu przez pokrzywdzonego wniosku o przesłanie mu takiej informacji, i to w terminie poprzedzającym wyznaczoną datę forum konsensualnego i w czasie umożliwiającym realne przesłanie pokrzywdzonemu odpowiednich danych ${ }^{83}$. Wezwanie lub zawiadomienie o terminie odbywania się forum procesowego $\mathrm{w}$ przedmiocie konsensualnych wniosków oskarżyciela publicznego lub samego oskarżonego musi być połączone z informacją o możliwości zakończenia postępowania w trybie kontraktowym oraz o uprawnieniu do sprzeciwienia się treści porozumienia pomiędzy oskarżonym a organami procesowymi. Zarówno wówczas, gdy kwestia konsensualnego skazania jest przedmiotem procedowania na

${ }^{83}$ K. Eichstaedt. W: B. AugustyniaK et al.: Kodeks postępowania karnego. Komentarz do zmian 2016..., s. 351; M. LASKOWsKI: Status pokrzywdzonego w procesie karnym po nowelizacji Kodeksu postępowania karnego z 27 września 2013 r. W: Wielka Nowelizacja procesu karnego. Red. J. GodyŃ, M. HudziK, L.K. PAPRZYCKI. Warszawa 2014, s. 110; M. RogaCKA-RzEWNICKA: Obrońca i petnomocnik wobec instytucji dobrowolnego poddania się karze. W: Obrońca i petnomocnik $w$ procesie karnym po 1 lipca 2013 r. Przewodnik po zmianach. Red. P. WiLIŃsKi. Warszawa 2015, s. 270. 
posiedzeniu, jak i na rozprawie pokrzywdzony przed przystąpieniem do rozpoznania wniosku o skazanie kontraktowe może złożyć oświadczenie konstytuujące go jako oskarżyciela posiłkowego.

Bez względu na procesowy status pokrzywdzony może na każdym $\mathrm{z}$ forum rozpoznania wniosku o wydanie wyroku kontraktowego korzystać z pomocy prawnej pełnomocnika ustanowionego $\mathrm{z}$ wyboru, natomiast usytuowanie się jeszcze przed rozprawą lub na rozprawie $\mathrm{w}$ roli strony otwiera mu możliwość ubiegania się o pomoc prawną z urzędu. Procesowa pozycja pokrzywdzonego została więc tak ukształtowana, by jeszcze przed rozpoczęciem forum procedowania konsensualnego wniosku o skazanie dysponował on kompletem informacji pozwalających mu na świadome zablokowanie uwzględnienia wniosku o skazanie za przestępstwo, którego opis jest pokrzywdzonemu znany ${ }^{84}$.

\section{Wyłączenie instancyjnej kontroli faktów sprawy stanowiących podstawę porozumień karnoprocesowych w perspektywie konstytucyjnej}

Podobnie kształtuje się zagadnienie koherencji zakazu podnoszenia zarzutu errores facti in iudicando w apelacji od wyroków kontraktowych z konstytucyjnie dopuszczalnymi wyjątkami od zasady zaskarżalności pierwszoinstancyjnych rozstrzygnięć. Oskarżony nie zostaje bowiem pozbawiony w sposób generalny prawa do spowodowania kontroli przed sądem usytuowanym w hierarchicznej strukturze sądów wyżej niż sąd rozstrzygający spór prawny, zakaz kwestionowania rekonstrukcji tkwiących u podstaw wyroku kontraktowego jedynie zawęża katalog dopuszczalnych zarzutów odwoławczych. Ratio przepisów wykluczających kontrolę rekonstrukcji tkwiących w podstawie faktycznej wyroków konsensualnych pozwala z kolei kategoryzować przyczyny ekscepcji od zasady kontroli pierwszoinstancyjnych rozstrzygnięć jako okoliczności na tyle ekstraordynaryjne, by w świetle wymogów orzecznictwa konstytucyjnego usprawiedliwić pozbawienie strony postępowania prawa do spowodowania wielo-

${ }^{84} \mathrm{~W}$ dyskusjach toczących się przed nowelizacją k.p.k. wzmocnienie pozycji pokrzywdzonego $\mathrm{w}$ trybach konsensualnych traktowano jako warunek jednoczesnego ograniczenie zaskarżalności wyroków kontraktowych poprzez limitowanie podstaw odwoławczych. Ponieważ pokrzywdzony nie bierze udziału w porozumieniu zawieranym w trybie art. 335 k.p.k. dla wprowadzenia limitów dopuszczalnych podstaw odwoławczych niezbędne jest, podobnie jak w art. 387 k.p.k., przyznanie pokrzywdzonemu możliwości sprzeciwienia się tej instytucji. Zob. S. SteInBorn: Sprawozdanie z dyskusji podczas konferencji „Model postępowania odwoławczego i kasacyjnego" - Warszawa 28 września 2010 r. (analiza problemowa). „Biuletyn Komisji Kodyfikacyjnej Prawa Karnego” 2010, z. 2, s. 294. 
aspektowej kontroli instancyjnej. Powodem ukonstytuowania zakazu podnoszenia zarzutu errores facti in iudicando było bowiem wykluczenie instrumentalnych zachowań partycypantów porozumienia procesowego, najpierw akceptujących kontrakt procesowy, następnie zaś zrywających dokonane ustalenia, po to by walczyć o korzystniejsze dla siebie rozstrzygnięcia w instancji odwoławczej. Niebezpieczeństwo nadużycia prawa jest szczególnie prawdopodobne $\mathrm{w}$ przypadku oskarżonego - uzgadniającego treść kontraktu przedkładanego następnie sądowi przez oskarżyciela publicznego albo wręcz samodzielnie suponującego zawartość treściową porozumienia procesowego. Istotą zachowań oskarżonego, przed którymi zabezpiecza zakaz podnoszenia zarzutu eksplikującego błąd rekonstrukcyjny, jest manipulowanie treścią oświadczeń dotyczących stanu faktycznego sprawy, by po zerwaniu kontraktu doprowadzić do uniewinnienia w sądzie odwoławczym lub rozpoznającym sprawę raz jeszcze ${ }^{85}$. Regulacje

${ }^{85}$ Pierwsza wersja przepisów statuujących ograniczenia zaskarżalności wyroków wydanych w trybie konsensualnym wyłączała działanie bezpośredniego i pośredniego zakazu reformationis in peius. Wyłączenia działania zakazu reformationis in peius spowodowało jednak nieakceptowalne konsekwencje. Posłużenie się sformułowaniem łączącym wyłączenie mechanizmu zabezpieczającego procesową pozycję oskarżonego wyłącznie z wydaniem wyroku kontraktowego, zgodnie z zasadą pierwszeństwa wykładni językowej, zaskutkowało bowiem zdjęciem ochrony wynikającej z zakazu reformationis in peius we wszystkich przypadkach skarg na wyroki konsensualne - lege non distinguente także tych, w których sąd samowolnie naruszył dokonane uzgodnienia, błędnie zastosował prawo materialne lub procedował z naruszeniem ordo processus. Dla zapobieżenia niepożądanym konsekwencjom wyłączenia zakazu reformationis in peius odpowiednie przepisy uzupełniono o opis przypadków zakwalifikowanych jako zachowania o charakterze instrumentalnym - verba legis założono, że czysto taktyczny charakter zgody na określone warunki skazania ma miejsce w każdym przypadku, gdy przedmiotem kontestacji korzystającego z benefitów porozumienia karnoprocesowego było rozstrzygnięcie co do winy lub wynegocjowanych środków penalnych (art. 434 \$ 3 w brzmieniu obowiązującym od dnia 1 lipca 2010 r.). Przepisy te funkcjonowały do dnia 30 czerwca 2015 r., nowelizacja przyjęta w dniu 27 września 2013 r. zastąpiła dotychczasowy mechanizm zabezpieczający przed instrumentalnymi zachowaniami oskarżonego zastąpiła art. 447 \$ 5 k.p.k. Zob. P. HofMAŃsKI, E. SADZIK, K. ZgrYZeK: Kodeks postępowania karnego. T. II: Komentarz do artykułów 297-467 k.p.k. Red. P. Hofmański. Warszawa 2004, s. 586; M. KLejnowsKa: Wyjatki od zakazu reformationis in peius. W: Problemy znowelizowanej procedury karnej. Red. Z. Sobolewski, G. Artymiak. C. P. KŁAK. Warszawa 2004, s. 377 i nast.; Idem: Zasada prawdy materialnej $w$ postępowaniu odwoławczym. W: Zasada prawdy materialnej. Red. Z. Sobolewski, G. ARTyMiak. Warszawa 2006, s. 260; IDEM: Ograniczenia sqdu odwoławczego orzekajacego w sprawie karnej po wniesieniu środka zaskarżenia. Rzeszów 2008, s. 301; W. KocIUBIŃsKI: Wytaczenie stosowania zakazu reformationis in peius $w$ wypadkach okreslonych $w$ art. $60 \$ 3$ i 4 kodeksu karnego oraz art. 343 lub art. 387 kodeksu postępowania karnego. Prok. i Pr. 2004, z. 10, s. 148; S. ZАвŁOCKI: Ograniczenie zakazu reformationis in peius, Pal. 2003, z. 7-8, s. 125; IDEM: Procesowe aspekty instrumentalnych poczynań tzw. małego świadka koronnego, ze szczególnym uwzględnieniem zakazu reformationis in peius. W: Wspótczesne problemy procesu karnego i wymiaru sprawiedliwości. Księga ku czci prof. 
ograniczające zaskarżalność wyroków konsensualnych ze względu na instrumentalne zachowania beneficjenta kontraktu procesowego nietrudno zakwalifikować jako zgodne z konstytucyjną regułą proporcjonalności, wyznaczającą modelowy sposób limitowania ogółu określonych ustawą zasadniczą praw i wolności (art. 31 ust. 3 Konstytucji RP). Ogół praw konstytucyjnych musi pozostawać w stanie wzajemnej koherencji, efektywność ich realizacji, może zatem wymagać swoistego balansowania pomiędzy nimi (balancing of interest) tak, by ewentualny konflikt zantagonizowanych praw wyeliminować poprzez wskazanie dobra uzyskującego przewagę nad drugim - i zapewnić mu silniejszą ochronę kosztem zawężenia prawa słabszego, wyważając zakres wzmocnienia i ograniczenia ochrony na tyle, by nie unicestwić możliwości korzystania z prawa słabszego, a jedynie ograniczyć zakres jego realizacji ${ }^{86}$. Poszczególne elementy delegacji dopuszczalnych ingerencji w sferę konstytucyjnych praw i wolności obejmują kolejno: 1) ustawową formę wprowadzenia zawężeń, 2) potrzebę zabezpieczenia przynajmniej jednej ze wskazanych wartości, tj. bezpieczeństwa państwa, porządku publicznego, ochrony środowiska, zdrowia publicznego, moralności publicznej oraz ochrony praw i wolności innych osób, oraz 3) zakaz naruszania istoty zawężanych praw, tj. minimalnej treści konkretnej wolności i prawa oraz nakaz zachowania zasady proporcjonalności pomiędzy rozmiarem ingerencji a wagą naruszonego prawa lub wolności ${ }^{87}$. Dokonanie operacji balancing of interests uzasadnia twierdzenie, że ograniczenie katalogu zarzutów mogących stanowić przedmiot apelacji od wyroku kontraktowego nie stanowi zbyt wygórowanej ceny za przeciwdziałanie manipulacyjnym zachowaniom partycypantów kontraktu. Wykluczenie możliwości skarżenia podstaw porozumienia przyczynia się bowiem $\mathrm{w}$ istotny sposób do usprawnienia i przyspieszenia postępowania karnego, tym samym zaś pozwala na za-

Kazimierza Marszała. Red. P. HofmańsKi, K. ZgryzeK. Katowice 2003, s. 502; S. Waltoś: Główne nurty nowelizacji procedury karnej. PiP 2003, z. 4, s. 17.

${ }^{86}$ L. GARLIcKI: Przestanki ograniczenia konstytucyjnych praw i wolności (na tle orzecznictwa Trybunatu Konstytucyjnego). PiP 2001, z. 10, s. 5; A. ŁABNo: Ograniczenie praw i wolności człowieka na podstawie art. 31 Konstytucji III RP. W: Prawo $i$ wolności obywatelskie $w$ Konstytucji RP. Red. B. BanaszaK, A. PreIsner. Warszawa 2002, s. 693 i nast.; M. WyrzyкоwsкI: Granice praw i wolności - granice władzy. W: Obywatel - jego wolności i prawa..., s. 58.

${ }^{87}$ L. GARLICKI: Przestanki ograniczenia konstytucyjnych praw i wolności (na tle orzecznictwa Trybunału Konstytucyjnego)..., s. 13; A. ŁABNo: Ograniczenie praw i wolności człowieka na podstawie art. 31 Konstytucji III RP..., s. 704 i nast.; K. WoJTYCzEK: Granice ingerencji ustawodawczej $w$ sferę praw człowieka $w$ Konstytucji RP. Kraków 1999, s. 140; IDEM: Zasada proporcjonalności. W: Prawo i wolności obywatelskie w Konstytucji RP..., s. 682; P. WILIŃsKI: Zasada prawa do obrony $w$ polskim procesie karnym..., s. 444 i nast.; M. WYRzYKowsKI: Granice praw i wolności - granice władzy. W: Obywatel-jego wolności i prawa..., s. 50. 
chowanie istoty trybów kontraktowych. Z perspektywy konstrukcyjnej konsensualne formy wyrokowania stanowią zredukowane postępowania szczególne, tj. postępowania $\mathrm{w}$ przedmiocie odpowiedzialności karnej różniące się $\mathrm{w}$ sposób istotny i przewidziany $\mathrm{z}$ góry przez ustawodawcę od formy zasadniczej. Zgodnie z typologią przyczyn uzasadniających wprowadzenie postępowań szczególnych racją istnienia trybów konsensualnych jest to, że sprawy będące ich przedmiotem nie wymagają sformalizowanej procedury, dla ich sfinalizowania - zgodnego z zasada prawdy i trafnej represji - wystarczająca jest bowiem procedura uproszczona ${ }^{88}$. Cel ukonstytuowania postępowań konsensualnych stanowiło bowiem odformalizowanie i skrócenie postępowania w tych sprawach, w których ze względu na odtworzenie okoliczności faktycznych na poziomie niebudzącym wątpliwości co do zgodności z obiektywnym przebiegiem zdarzenia faktycznego oraz zdolności oskarżonego do ponoszenia winy oskarżyciel i oskarżony osiągnęli konsensus co do treści rozstrzygnięcia sądowego ${ }^{89}$. Szczególny układ okoliczności faktycznych spowodował, że bez obawy o ograniczenie lub zdyskwalifikowanie zasady prawdy i trafnej

${ }^{88}$ D. GIL: Postępowanie $w$ sprawach z oskarżenia prywatnego $w$ polskim procesie karnym. Warszawa 2011, s. 37; D. Kala: Tryby szczególne w kodeksie postępowania karnego w świetle poglądów reprezentowanych $w$ doktrynie i judykaturze. Toruń 2005, s. 20; A. GaberLe, S. Waltoś: Postępowania szczególne w polskim procesie karnym. Model a praktyka. „Zeszyty Naukowe Instytutu Badania Prawa Sądowego" 1977, z. 7, s. 137; A. ŚwiATŁowski: Jedna czy wiele procedur karnych. Z zagadnień wewnętrznego zróżnicowania form postępowania karnego rozpoznawczego. Sopot 2009, s. 109.

89 T. GRZEgorCzYK: Wniosek oskarżonego o skazanie go bez przeprowadzenia postępowania dowodowego na rozprawie. PS 2001, z. 1, s. 16 i nast.; W. JAsIŃsKI: Instytucje skazania bez rozprawy (art. 335 k.p.k.) oraz dobrowolnego poddania się odpowiedzialności karnej (art. 387 k.p.k.) na tle naczelnych zasad procesu karnego. Prok. i Pr. 2005, z. 9, s. 15 i nast.; R. KoPER: Warunki skazania oskarżonego wyrokiem bez rozprawy..., s. 78; J. MENTEL: Wniosek oskarżonego o skazanie bez przeprowadzenia postępowania dowodowego (art. 387 k.p.k.). W: Nowa kodyfikacja prawa karnego. T. 9. Red. L. BogUnIA. Wrocław 1997, s. 119 i nast.; D. NowocIEŃ: Instytucja „dobrowolnego poddania się karze” $w$ Kodeksie postępowania karnego z 1997 r. W: Nowa kodyfikacja prawa karnego. T. 1. Red. L. Bogunia. Wrocław 1997, s. 177 i nast.; R. PoniKowski: Wniosek oskarżonego o wydanie wyroku skazujacego bez przeprowadzenia postępowania dowodowego - art. 387 nowego kodeksu postępowania karnego. W: Nowa kodyfikacja prawa karnego, T. I..., s. 181; P. RogozIŃski: Dobrowolne poddanie sie przez oskarżonego odpowiedzialności karnej. PiP 2000, z. 9, s. 54; R.A. STEFAŃsKI: Skazanie bez rozprawy znowelizowanym kodeksie postępowania karnego. Prok. i Pr. 2003, z. 6, s. 28; S. SteInBorn: Porozumienia $w$ polskim procesie karnym. Warszawa 2005, s. 261 i nast.; L. WiLK: Instytucja skróconej rozprawy jako przykład konsensualnego zakończenia procesu karnego - art. 387 k.p.k. Prok. i Pr. 2005, z. 1, s. 87 i nast.; IDEM: Instytucja skróconej rozprawy $w$ trybie art. 387 k.p.k. PS 2005, z. 1, s. 152 i nast.; A. ZACHUTA: Proces karny skrócony. Pal. 2000, z. 7-8, s. 58 i nast.; M. ZвRоJEwsка: Dobrowolne poddanie się karze $w$ kodeksie postępowania karnego. Białystok 2002; IDEM: Dobrowolne poddanie się karze w świetle orzecznictwa Sądu Najwyższego. PS 2001, z. 11-12, s. 206 i nast. 
represji ustawodawca mógł potraktować wprowadzenie trybów konsensualnych jako sposób na potencjalne oszczędności procesowe, tj. ograniczenie zakresu postępowania przygotowawczego (art. 335 §1 k.p.k.), rezygnacji z przeprowadzenia rozprawy i skazanie oskarżonego na posiedzeniu bez przeprowadzania postępowania dowodowego (art. 335 w zw. z art. 343 k.p.k. oraz art. 338a w zw. z art. 343a k.p.k.) lub ograniczenie zakresu postępowania dowodowego na rozprawie i skazanie oskarżonego na podstawie jego wyjaśnień oraz - nieprzeprowadzonych przed sądem, a tylko ujawnionych na rozprawie - dowodów wymienionych w akcie oskarżenia lub dokumentów przedłożonych przez strony (art. 387 §5 k.p.k. ${ }^{90}$. Zakaz podnoszenia zarzutu errores facti in iudicando $\mathrm{w}$ apelacji od wyroków objętych porozumieniem karnoprocesowym gwarantuje też efektywność postępowania, niemożność zaatakowania ustaleń faktycznych tworzących ramę do wyrażenia zgody na konsensualne zakończenie postępowania oraz niemożność oprotestowania treści wynegocjowanych ustaleń, pozwala bowiem chronić trwałość konsensusu. Osiągnięcie obu prakseologicznych względów stanowiących immanentne cechy trybów konsensualnych, tj. usprawnienia i przyspieszenia postępowania karnego oraz zapewnienia mu efektywność, niewątpliwie leży w interesie wymiaru sprawiedliwości, ich realizację - nawet kosztem ograniczenia pewnych gwarancji procesowych - można więc potraktować jako niezbędne dla ochrony porządku prawnego oraz wolności i praw innych osób, tj. dla osiagnięcia konstytucyjnych kryteriów pozytywnego wyniku testu proporcjonalności.

\section{Całkowita likwidacja kontroli faktycznej podstawy orzeczenia w kontekście prawnomiędzynarodowej i konstytucyjnej zasady zaskarżalności wyroków pierwszoinstancyjnych}

O równie pewne wnioski trudno w przypadku kwestii trwałego zniesienia instancyjnego kontrolowania errores facti in iudicando na poziomie ustawodawstwa zwykłego. W doktrynie wyrażono ${ }^{91}$ i konsekwentnie pod-

${ }^{90}$ P. Hofmański, E. SAdziK, K. ZgrYZeK: Kodeks postępowania karnego. T. II..., s. 407; A. MuRzYNowsKI: Ogólna charakterystyka nowego Kodeksu postępowania karnego. PiP 1997, z. 9, s. 7; T. GRZEgorCzYK: O niektórych uproszczeniach procedury karnej w nowym Kodeksie postępowania karnego. PS 1997, z. 9, s. 9; S. WaLtoś: Nowa polska procedura karna a oczekiwania społeczne. PiP 1998, z. 9-10, s. 104; Z. GostYŃski: Zasada szybkości w nowym Kodeksie postępowania karnego. W: Nowy Kodeks postępowania karnego. Zagadnienia węzłowe. Red. E. SKrętowicz. Kraków 1998, s. 381.

${ }^{91}$ S. STEINBorn: Ograniczenie zaskarżalności wyroku wydanego w I instancji jako środek uproszczenia procesu karnego $w$ świetle prawa do dwuinstancyjnego postępowania (uwagi de lege lata i de lege ferenda). W: Gdańskie Studia Prawnicze. Prawa człowieka..., s. 382. 
trzymywano stanowisko ${ }^{92}$, że wyłączenie z zakresu kontroli odwoławczej ustaleń faktycznych, de nomine koherentne ze standardem strasburskim, de facto uniemożliwia gwarantowane art. 2 ust. 1 Protokołu numer 7 do Konwencji o Ochronie Praw Człowieka i Podstawowych Wolności zweryfikowanie prawidłowości rozstrzygnięcia o winie. Pogląd o rzeczywistej niezgodności zakazu podważania stanu faktycznego ze standardem konwencyjnym opiera się na założeniu, że prawidłowa analiza i korekta orzeczenia o winie jest immanentnie sprzężona $z$ kontrola ustaleń faktycznych stanowiących podstawę przypisania odpowiedzialności karnej oskarżonemu. Sprzeczność trwałego usunięcia instancyjnej kontroli ustaleń faktycznych miałyby więc dyktować przede wszystkim względy natury technicznej, związane z niemożnością odseparowania analizy prawidłowości przypisania winy i rekonstrukcji tkwiących u podstawy tego rozstrzygnięcia ${ }^{93}$. Wydaje się jednak, że sprzeczność trwałego zamknięcia drogi do kontroli odwoławczej faktów sprawy z prawnomiędzynarodowym standardem wynika $\mathrm{z}$ różnego rozumienia terminów użytych na oznaczenie elementów wyroku objętych gwarancją zaskarżenia, tj. orzeczenie $\mathrm{w}$ przedmiocie winy $\mathrm{i}^{94} / \mathrm{lub}^{95}$ rozstrzygnięcia co do kary. Ponieważ zarówno art. 14 ust. 5 Międzynarodowego Paktu Praw Obywatelskich i Politycznych, jak i art. 2 ust. 1 Protokołu nr 7 do Konwencji o Ochronie Praw Człowieka i Podstawowych Wolności używają formuł odwołujących się do odpowiednich fragmentów orzeczenia, przyjąć należy, że termin „orzeczenie o winie” oznacza odpowiednią część struktury części dyspozytywnej wyroku sądu pierwszej instancji ${ }^{96}$. Formuła „orzeczenie o winie” ma charakter autonomiczny, wina w ujęciu procesowym (wina sensu largo) posiada swoistą treść proceduralną i nie wykazuje symetrii wobec karnomaterialnego pojęcia winy ${ }^{97}$. Wina $\mathrm{w}$ aspekcie procesowym obejmuje bowiem całokształt przesłanek odpowiedzialności karnej, ergo wina w sensie procesowym jest realną zaszłością historyczną, tj. czynem o określonych

92 P. Wiliński: Proces karny w świetle Konstytucji. Warszawa 2011, s. 158; W. JasińsKI, M. KuźmA: Granice i zaskarżalność porozumień procesowych. W: Współzależność prawa karnego materialnego $i$ procesowego $w$ świetle kodyfikacji karnych z 1997 r. i propozycji ich zmian. Red. Z. ĆWiąKalski, G. ARTYMiaK. Warszawa 2009, s. 328.

${ }^{93}$ P. van DiJK, G.J.H. van Hoof: Theory and Practice of the European Covnvention on Human Rights..., s. 686.

${ }^{94} \mathrm{~W}$ art. 14 ust. 5 Międzynarodowego Paktu Praw Obywatelskich i Politycznych.

${ }^{95} \mathrm{~W}$ art. 2 ust. 2 Protokołu nr 7 do Konwencji o Ochronie Praw Człowieka i Podstawowych Wolności.

${ }^{96} \mathrm{O}$ strukturze części dyspozytywnej wyroku zob. M. KościelniaK-Marszat: Wyrok sqqdu I instancji. Warszawa 2017 r., s. 102 i nast.

${ }^{97}$ P. HofmańsKi. W: Konwencja o Ochronie Praw Człowieka i Podstawowych Wolności. Komentarz do art. 19-59 oraz do Protokołów dodatkowych. T. II..., s. 635. 
cechach $^{98}$. Odpowiedzialność karna sprawcy może się urzeczywistnić dopiero $\mathrm{w}$ razie zaistnienia winy $\mathrm{w}$ płaszczyźnie materialnoprawnej i procesowej, tj. w razie zarzucalności winy traktowanej jako pewna właściwość powstająca $\mathrm{w}$ chwili czynu przestępnego i przypisywalności winy w drodze procesu karnego. Proces karny stanowi bowiem wyłączną płaszczyznę postawienia zarzutu popełnienia danego czynu, ewentualnego przyznania się oskarżonego do winy oraz pozytywnego lub negatywnego rozstrzygnięcia w przedmiocie winy. Komponenty orzeczenia o winie w ujęciu procesowym stanowi więc zarówno wina $\mathrm{w}$ aspekcie materialnoprawnym, jak również bezprawność zaszłości historycznej, stopień jej społecznej szkodliwości, a ponadto takie kwestie jak: wyczerpanie zachowaniem sprawcy wszystkich znamion czynu zabronionego, strona podmiotowa czynu zabronionego, postać zjawiskowa i forma stadialna przestępstw, kwalifikacja prawna czynu czy też istnienie związku przyczynowego pomiędzy zachowaniem sprawcy a skutkiem czynu, a także dowodowe ustalenie sprawstwa czynu zabronionego ${ }^{99}$. Rozstrzygnięcie przypisujące winę czy też uznające oskarżonego za winnego - eksplikowane poprzez formułę „oskarżonego uznaje się za winnego popełnienia zarzucanego mu czynu" - oznacza spełnienie ogółu materialnoprawnych i procesowych warunków odpowiedzialności karnej. Substratem procesowego ujęcia winy jest jej przypisywalność, pozytywne rozstrzygnięcie w przedmiocie winy następuje więc po stwierdzeniu wszystkich warunków odpowiedzialności ustalanych ex post w procesie karnym, tj. warunków subiektywnych i, przy założeniu spełnienia warunków obiektywnych, możliwości przypi-

${ }^{98}$ M. CIEŚLAK: Polskie prawo karne. Zarys systemowego ujęcia. W: M. CIEŚLAK: Dzieła wybrane. T. III. Red. S. Waltoś. Kraków 2011, s. 248; L. Gardocki: Prawo karne. Warszawa 2011, s. 53; R. Кміесік. W: Prawo dowodowe. Zarys wyktadu. Red. R. KMIEcIK. Kraków 2005, s. 139, przyp. 61; IDEM: Glosa do postanowienia Sądu Najwyższego z dnia 29 kwietnia 1997 r., V KKN 266/97. OSP 1997, z. 12, s. 634; IDEM. W: R. КMIECIK, E. SKRĘTOWICZ: Proces karny. Część ogólna. Warszawa 2009, s. 294, przyp. 94; W. SIERACKI: Próba określenia zakresu części wyroku „dotyczącej orzeczenia o winie” (art. 395 k.p.k.). „Wojskowy Przegląd Prawniczy" 1994, z. 1, s. 58 i nast.; S. STEInborn: Prawomocność części orzeczenia $w$ procesie karnym. Warszawa 2011, s. 273; D. ŚwIECKI: Wina w prawie karnym materialnym i procesowym. Prok. i Pr. 2009, z. 11-12, s. 10 i nast.; A. WĄSEK: O niektórych niespójnościach unormowań kodeksu karnego i kodeksu postępowania karnego. W: Aktualne problemy prawa i procesu karnego. Ksiega ofiarowana Profesorowi Janowi Grajewskiemu..., s. 58 i nast.; A. JEZUSEK: „Domniemanie winy” $w$ prawie karnym materialnym a procesowe domniemanie niewinności. RPEiS 2016, z. 2, s. 166.

${ }^{99}$ M. CIEŚLAK: Polskie prawo karne. Zarys systemowego ujęcia. W: M. CIEŚLAK: Dzieła wybrane. T. III..., s. 248; D. ŚwIECKI: Wina $w$ prawie karnym materialnym i procesowym..., s. 9; IDEM: Granice orzekania na niekorzyść oskarżonego na podstawie art. 434 \$1 i art. 443 k.p.k. PS 2009, z. 5, s. 68 i nast.; S. STEINBORn: Prawomocność części orzeczenia $w$ procesie karnym..., s. 273; 
sania czynu ${ }^{100}$. Orzeczeniem o winie nie jest zatem orzeczenie, w którym sąd jedynie stwierdza zawinienie $\mathrm{w}$ rozumieniu prawa materialnego, tylko orzeczenie przypisujace osobie oskarżonej sprawstwo zarzucanego jej czynu. Rekonstrukcję zdarzenia przestępnego należy kategoryzować więc jako komponent orzeczenia o winie $\mathrm{w}$ znaczeniu procesowym znajdującego się strukturze części dyspozytywnej wyroku sądu pierwszej instancji. Weryfikacja sposobu odtworzenia faktów prawnie relewantnych stanowi więc komponent prawnomiędzynarodowych gwarancji instancyjnej kontroli orzeczenia o winie, co na poziomie ustawodawstwa zwykłego wyklucza zniesienie kontrolowania errores facti in iudicando w sposób trwały i powszechny, tj. w zakresie wszystkich wyroków skazujących. Dokonanie operacji balancing of interests uzasadnia twierdzenie, że wykluczenie z katalogu zarzutów mogących stanowić przedmiot apelacji od każdego wyroku karnego, błędu rekonstrukcyjnego stanowiłoby wyraźną preferencję zasady szybkości postępowania. Skrócenie czynności sądowego stosowania prawa poprzez eliminację kontroli faktów tkwiących w podstawie faktycznej rozstrzygnięcia niewątpliwie mocno sprzyja realizacji prakseologicznych wartości arbitralnego rozstrzygania konfliktów ${ }^{101}$. Uznanie jakiegoś faktu za rzeczywisty bez możliwości poddania weryfikacji prawdziwościowej procesowego wyobrażenia o czynie zwiększa więc szybkość sądowego stosowania prawa ${ }^{102}$. Czynniki dynamizujące lub hamujące przebieg procesu

${ }^{100}$ I. ANDREJEW: O pojęciu winy w polskim prawie karnym. PiP 1982, z. 7, s. 49.

${ }^{101}$ J. WróblewsKi: Wartości a decyzja sądowa..., s. 166 i nast.

102 O konieczności zdynamizowania przebiegu poszczególnych etapów sądowego stosowania prawa zob. M. CIEŚLAK: Zagadnienia dowodowe $w$ procesie karnym. W: M. CIEŚLAK: Dzieła wybrane. T. I. Red. S. WaLtoś. Kraków 2011, s. 228-229; Zagubiona szybkość procesu karnego. Jak ja przywrócić?. Red. S. Waltoś, J. CzAPSKA. Warszawa 2005; Zagubiona szybkość procesu karnego. Światło w tunelu. Red. S. Waltoś, J. CzapsKa. Warszawa 2007. Starania o przyspieszenie czynności umożliwiających sądowe rozstrzygnięcie konfliktu stanowi ratio legis poszczególnych nowelizacji Kodeksu postępowania karnego z dnia 6 czerwca 1997 r. zob. w szczególności Uzasadnienie do projektu Kodeksu karnego i Kodeksu postępowania karnego. W: Kodeks karny. Kodeks postępowania karnego. Kodeks karny wykonawczy: nowe kodeksy karne - z 1997 r. z uzasadnieniami. Red. I. Fredrich-MichalsKA, B. STACHURSKA-MARCIŃCZAK. Warszawa 1997, s. 393 i nast.; Uzasadnienie rzq̨dowego projektu ustawy o zmianie ustawy Kodeks postępowania karnego, ustawy - Kodeks karny i niektórych innych ustaw (Druk Sejmowy nr 870). Źródło: http://www.sejm.gov.pl/Sejm7.nsf/druk. xsp?nr=870 [dostęp: 27.09.2018]; J. GRAJEWSKI et al.: O tak zwanym upraszczaniu procesu karnego. W: Węzłowe problemy procesu karnego. Red. P. Hofmański. Warszawa 2010, s. 713 i nast.; A. KryżE: Nowe instytucje majace wptyw na sprawność postępowania i procedury dowodowej. „Jurysta” 1999, z. 11-12; R.A. STEFAŃsKi: Przyszły model postępowania przygotowawczego. IN 2009, z. 1, s. 28; IDEM: Krytycznie o obecnym modelu postępowania przygotowawczego. W: Węztowe problemy procesu karnego. Red. P. Hofmański. Warszawa 2010, s. 146 i nast.; S. WaLtoś: Główne nurty nowelizacji procedury karnej. PiP 2003, z. 4, s. 5 i nast.; W. GrzeszczyK: Gtówne kierunki zmian kodeksu postępowania karnego (cz. II). Prok. i Pr. 2003, z. 6, s. 7 i nast. O negatywnych aspektach procesu dynamizowania modelu sądowe- 
poznawania faktów relewantnych dla sądowego rozstrzygnięcia konfliktu wiążą się bowiem zarówno z czynnościami rekonstrukcyjnymi, cechami materiału prawnego i faktycznego składających się na mniejszą i większą przesłankę sylogizmu prawniczego, właściwościami podmiotu poznającego i decyzyjnego, ale również z obowiązującym modelem decyzyjnym. Dążenie do realizacji prakseologicznych udogodnień oszczędnościowych nie może jednak skutkować brakiem możliwości, czy chociażby zmniejszeniem prawdopodobieństwa dotarcia do prawdy materialnej. Dążenie do szybkiego przeprowadzenia procesu jest możliwe jedynie o tyle, o ile nie koliduje z zasadą prawdy materialnej. Jej realizację powinna gwarantować całość przepisów karnoprocesowych, bowiem skoro przedmiotem procesu karnego jest kwestia odpowiedzialności oskarżonego za zarzucany mu czyn, rozstrzygnięcie w przedmiocie procesu jest bezpośrednio zależne od dokonania prawdziwych ustaleń faktycznych ${ }^{103}$. Wzgląd na samą sprawność procedury z pewnością jednak nie może mieć bezwzględnie priorytetowego charakteru, prakseologiczne zalecenie symplifikacji działań celowych za pomocą jak najprostszych form, oszczędzających zasób wydatkowanych w procesie realizacji zamierzonego stanu rzeczy własnych sił, ofiar, strat czy też wkładów ${ }^{104}$ nie może bowiem stanowić na gruncie procesu karnego wartości autotelicznej ${ }^{105}$, tak by dla jej realizacji w sposób trwały silnie limitować uprawnienia stron wiążące się z obroną ich praw i wolności. Prakseologia określonych rozwiązań nie może więc sta-

go stosowania prawa zob. A. GABERLE: Zasada trafnej reakcji na przestępstwo a postępowanie uproszczone, przyspieszone i nakazowe. W: Problemy kodyfikacji prawa karnego. Ksiega ku czci Profesora Mariana Cieślaka. Red. S. Waltoś. Kraków 1993, s. 538 i nast.; W. GLINIECKI: Przyspieszanie i upraszczanie postępowania karnego a ochrona interesów pokrzywdzonego. Prok. i Pr. 2007, z. 2, poz. 66 i nast.; J. GRAJEwSKI, S. STEINBORN: Zasada prawdy materialnej jako granica upraszczania procesu karnego. W: Zasada prawdy materialnej. Materiaty z konferencji. Krasiczyn 15-16 października 2005 r. Red. Z. Sobolewsкi, G. ARTYмiaK. Kraków 2006, s. 207 i nast.; A. MurzYNowsKi: Refleksje na temat przestrzegania zasady prawdy materialnej a zachowanie sprawności postępowania karnego. W: Aktualne problemy prawa i procesu karnego. Ksiega ofiarowana Profesorowi Janowi Grajewskiemu..., s. 110 i nast.

103 J. Grajewski, S. SteInborn: Zasada prawdy jako granica upraszczania procesu karnego..., s. 209.

${ }^{104}$ T. Kotarbiński: Traktat o dobrej robocie. Wrocław-Warszawa-Kraków-Łódź 1982, s. 386; IDEM: Zasady dobrej roboty. Łódź 1946, s. 623 i nast.; IDEM: Abecadto praktyczności. Warszawa 1974, s. 44 i nast.; IDEM: Hasło dobrej roboty. Warszawa 1975, s. 48 i nast.; T. PszczóŁKowsкi: Zasady sprawnego działania. Warszawa 1975; IDEM: Dylematy sprawnego działania. Warszawa 1982, s. 175 i nast.; T. Tyszka: Prakseologia podejmowania decyzji. „Prakseologia” 1977, z. 1-2, s. 209 i nast.; Z. WAsIUTYŃski: O zasadach najmniejszego i największego wysitku i o współzawodnictwie. „Prakseologia” 1971, z. 39-40, s. 3.

105 Wyrok TK z dnia 12 marca 2002 r., P 9/01, OTK-A 2002, nr 2, poz. 14; wyrok TK z dnia 12 czerwca 2002 r., P 13/01, OTK-A 2002, nr 4, poz. 42; wyrok TK z dnia 13 stycznia 2004 r., 10/03, OTK-A 2004, nr 1, poz. 2; wyrok TK z dnia 20 września 2006 r., SK 63/05, OTK-A 2006, nr 8, poz. 108. 
nowić samoistnej przesłanki legitymizującej legalność uszczuplenia konstytucyjnego prawa do instancyjnej kontroli orzeczenia.

Przeciwskazaniem dla wyabstrahowania kontroli instancji od analizy prawidłowości stanu faktycznego stanowi ponadto, generowane tego typu redukcją, przemodelowanie wielopłaszczyznowej działalności weryfikacyjnej realizowanej w ramach typowego przebiegu instancyjnego, gwarantowanego standardem międzynarodowym i konstytucyjnym, w kontrolę zbliżoną do analizy i korekty specyficznej dla nadzwyczajnych trybów postępowania kontrolnego. Prawo do skorzystania z nadzwyczajnego środka zaskarżenia nie stanowi zasady konstytucyjnej; konstytucyjna zasada dostępu do sądu (art. 77 ust. 2 Konstytucji RP) gwarantuje co prawda, że na poziomie ustawodawstwa zwykłego niedopuszczalne jest zamknięcie drogi sądowej dochodzenia naruszonych wolności i praw, jednak, ze względu na ograniczenie konstytucyjnego standardu do kontroli instancyjnej, przepis o dostępie do sądu nie daje podstawy do wywodzenia reguły dochodzenia praw poza tokiem instancji. Konstytucja RP statuując wymóg co najmniej dwuinstancyjnego postępowania w pozostałym zakresie pozostawia zatem swobodę $\mathrm{w}$ kształtowaniu modelu systemu środków pozainstancyjnej kontroli orzeczeń na poziomie ustawodawstwa zwykłego. Ograniczenie dostępności do nadzwyczajnego środka odwoławczego nie narusza też prawnomiędzynarodowego standardu kontroli orzeczeń, art. 2 ust 1 Protokołu numer 7 do Konwencji o Ochronie Praw Człowieka i Podstawowych Wolności oraz w art. 14 ust. 5 Międzynarodowego Paktu Praw Obywatelskich i Politycznych jednoznaczne dekretują wyłącznie instancyjną zaskarżalność wyroków skazujących w sprawach karnych, żaden $\mathrm{z}$ nich nie rozciąga zatem prawa do sądu na rozpoznanie sprawy poza tokiem instancji ${ }^{106}$. Kontrola w trybach nadzwyczajnych, nieobjętych minimalnym standardem instancyjnej weryfikacji orzeczeń, może więc podlegać redukcjom w zakresie dostępu do sądu, pod warunkiem jednak ich niearbitralności, zachowania odpowiedniej proporcjonalności i racjonalności ${ }^{107}$ oraz korelacji z konstytucyjnym porządkiem ${ }^{108}$.

${ }^{106}$ P. Hofmański, A. Wróbel. W: Konwencja o Ochronie Praw Człowieka i Podstawowych Wolności. Komentarz do art. 1-18. T. I..., s. 290; T. ERECIŃsKI: Ograniczenia $w$ dostępności kasacji $w$ sprawach cywilnych. W: Prace $z$ prawa prywatnego. Ksiega pamiatkowa ku czci Sędziego Janusza Pietrzykowskiego. Red. Z. BanaszczyK. Warszawa 2000, s. 79.

${ }^{107} \mathrm{O}$ tym, że ograniczenia dostępu do drogi sądowej są dopuszczalne, o ile nie naruszają istoty prawa do sądu, nie są nieproporcjonalne i mają racjonalne uzasadnienie zob. wyrok ETPC z dnia 23 listopada 1993 r. w sprawie Smyk p. Polsce (skarga nr 895/04), LEX nr 511261; wyrok ETPC z dnia 15 lutego 2000 r. w sprawie Garcia Manibardo p. Hiszpanii (skarga nr 38695/97), LEX nr 76901.

${ }^{108}$ Wyrok TK z dnia 17 maja 2004 r., SK 32/03, wraz z glosą aprobującą: A. ŚwIATŁowsKi: Glosa do wyroku Trybunatu Konstytucyjnego z dnia 17 maja 2004 r., SK 32/03. Prok. i Pr. 2005 , z. 5, s. 121 i nast. 
Potencjalne ograniczenia w zakresie prawa do skorzystania z nadzwyczajnych środków odwoławczych są nieweryfikowalne z perspektywy uniwersalnej zasady zaskarżalności orzeczeń i decyzji w instancyjnym przebiegu procesu; przepisy limitujące mogą być jednak kontrolowane $\mathrm{z}$ innymi konstytucyjnymi wzorcami, exempli gratia konstytucyjny wzorzec umożliwiający kontrolę konstytucyjności ograniczeń w dostępie do kontroli pozainstancyjnej może stanowić przewidziany $\mathrm{w}$ art. 2 Konstytucji RP kanon demokratycznego państwa prawnego ${ }^{109}$, określona w art. 32 ust. 1 zasada równości wobec prawa ${ }^{110}$ czy też eksplikowana normą art. 42 ust. 1 Ustawy Zasadniczej gwarancja rzetelnego procesu ${ }^{111}$. Tymczasem immanentnym atrybutem kontroli apelacyjnej jest jej wieloaspektowość, przedmiot zainteresowania sądu odwoławczego może stanowić bowiem analiza zgodności zakwestionowanego orzeczenia z prawem materialnym i procedurą, sprawdzanie zgodności ustaleń faktycznych stanowiących podstawę kontrolowanego orzeczenia z obiektywną rzeczywistością oraz analiza trafności i sprawiedliwości rozstrzygnięć zawartych w zakwestionowanym orzeczeniu (art. 438 k.p.k.) ${ }^{112}$. Właściwa równowaga pomiędzy stabilnością prawomocnych orzeczeń sądowych i potrzebą eliminacji najpoważniejszych błędów je obciążających determinuje ograniczenie zakresu kontroli odbywającej się w trybach nadzwyczajnych wyłącznie do analizy zgodności treści wyroku z prawem materialnym oraz istotnych uchybień proceduralnych popełnionych w postępowaniu poprzedzającym jego wydanie. Delimitacja kontroli ustaleń faktycznych i prawidłowości w stosowaniu prawa stanowi fundamentalny atrybut kontroli odwoław-

109 Nowe uregulowania prawne w kodeksie postępowania karnego z 1997 r. Red. P. KRUSZYর́sKI. Warszawa 1999, s. 411.

${ }^{110}$ Wyrok TK z dnia 17 maja 2004 r., SK 32/03.

${ }^{111}$ Zasada rzetelnego procesu stanowi uznany w orzecznictwie ETPC wzorzec kontroli poprawności przepisów limitujących w danej kategorii spraw dostęp do sądu odwoławczego lub kasacyjnego, utrwalona linia orzecznictwa przyjmuje bowiem, że jeżeli wewnątrzkrajowy porządek prawny umożliwia dostęp do procedur nadzwyczajnych kontrola pozainstancyjna powinna być zgodna z zasadą rzetelnego procesu określoną w art. 6 Konwencji o Ochronie Praw Człowieka i Podstawowych Wolności; zob. decyzja ETPC z dnia 14 grudnia 1989 r. w sprawie X. p. Austrii (skarga nr 16598/89); decyzja ETPC z dnia 9 stycznia 1995 r. w sprawie M.M. p. Francji (skarga nr 20373/92). O tym, że regulacje dostępu do sądu odwoławczego oraz kasacyjnego muszą być tak skalibrowane, by kontrola instancyjna i pozainstancyjna spełniała standardy wynikające z zasady rzetelnego procesu zob. też A. ŁAZARSKA: Rzetelny proces cywilny. Warszawa 2012, s. 305.

${ }^{112}$ K. ŁoJEWsKI: Apelacja karna. Warszawa 2003, s. 3 i nast.; K. MARsZAŁ: System apelacyjno-kasacyjny w polskim procesie karnym. SI 1997, z. XXXIII, s. 164; Z. MuRAs: Postępowanie odwoławcze $w$ procesie karnym. Artykuty 425-467 k.p.k. Komentarz. Warszawa 2004, s. 126; S. Pawela: Względne przyczyny odwoławcze. Warszawa 1970, s. 10; W. GrzeszczYK: Nowa kodyfikacja karna. Kodeks postępowania karnego. Krótkie komentarze. Z. 5. Warszawa 1997, s. 73. 
czej w apelacyjno-kasacyjnym modelu zwyczajnej i nadzwyczajnej ewaluacji orzeczeń; w ramach tak skonstruowanego systemu apelacja implikuje sprawdzalność słuszności odtworzeń tkwiących w podstawie faktycznej rozstrzygnięcia oraz zgodności zaskarżonego orzeczenia z obowiązującym prawem, natomiast kasacja nakierowuje się wyłącznie na weryfikację rozstrzygnięcia pod względem prawnym ${ }^{113}$. Statuowanie ograniczeń eliminujących z trybu kontroli instancyjnej weryfikację poprawności ustaleń faktycznych, implikując pozbawienie strony możliwości poddania orzeczenia sprawdzeniu i korekcie z perspektywy uchybień weryfikowalnych wyłącznie w toku kontroli apelacyjnej, niesprawdzalnych już w nadzwyczajnym trybie odwoławczym, istotnie koliduje więc z modelem dwuinstancyjnego przebiegu postępowania karnego.

\section{Bibliografia}

\section{Literatura}

ANDREJEW I.: O pojęciu winy w polskim prawie karnym. PiP 1982, z. 7.

ARTYMiAK G.: „Instancja pozioma” jako jedna z propozycji usprawnienia postępowania karnego - uwagi de lege lata i de lege ferenda. W: Funkcje procesu karnego. Ksiega jubileuszowa Profesora Janusza Tylmana. Red. T. GrzegorczyK. Warszawa 2011.

Arystoteles: Etyka nikomachejska. Tłum. D. GromsKa. W: Arystoteles: Dzieła wszystkie. T. V. Warszawa 2002.

${ }^{113}$ Z. DodA, J. GrajewsKI, A. MurzynOwsKI: Kasacja w postępowaniu karnym. Komentarz. Warszawa 1996, s. 18; P. HoFMAŃsKI, S. ZABŁOCKI: Funkcjonalność postępowania kasacyjnego $w$ świetle nowego kodeksu postępowania karnego. W: Nowa kodyfikacja karna. Kodeks postępowania karnego. Zagadnienia węzłowe. Red. E. SKrętowicz. Warszawa 1997, s. 67; W. GrzeszCzYK: Kasacja w sprawach karnych. Kraków 2001, s. 142; IdEM: Oczywista bezzasadność kasacji w świetle orzecznictwa Sąu Najwyższego. Prok. i Pr. 2002, z. 11, s. 153; R. Кміесік: Kasacja jako nadzwyczajny środek zaskarżenia wyroku (kilka uwag de lege ferenda $w$ związku z unormowaniami k.p.k. z 1997 r.). W: Polska lat dziewięćdziesiątych. Przemiany państwa i prawa. T. 2. Red. L. AnTonowicz et al. Lublin 1998, s. 289 i nast.; IDEM: Trójinstancyjny system apelacyjno-kasacyjny czy dwuinstancyjna hybryda rewizyjno-kasacyjna?. W: Kierunki i stan reformy prawa karnego..., s. 66 i nast.; A. KoRDIK: Kasacja $w$ świetle przepisów nowego kodeksu postępowania karnego. Uwagi dyskusyjne. W: Nowa kodyfikacja prawa karnego. Red. L. Bogunia. Wrocław 1997, s. 134 i nast.; K. MarsZAŁ: System apelacyjno-kasacyjny $w$ polskim procesie karnym. W: Węzłowe zagadnienia procedury karnej. Księga ku czci Profesora Andrzeja Murzynowskiego. SI 1997, t. 33. Red. P. KruszyósKi; A. MurzYnowski: Rozważania na temat modelu kasacji. W: Problemy kodyfikacji prawa karnego. Ksiegga ku czci Profesora Mariana Cieślaka. Red. S. Waltoś. Kraków 1993, s. 519 i nast.; L.K. PAprzycki: Model kasacji w polskiej procedurze karnej. Pal. 2008, z. 7-8, s. 9 i nast.; M. Rogacka-Rzewnicka: Kasacja $w$ polskim procesie karnym. Warszawa 2001, s. 206; M. ZвRojewsKa: Rola i stanowisko prawne Sądu Najwyższego w procesie karnym. Warszawa 2013, s. 264. 
AugustyniaK B. et al.: Kodeks postępowania karnego. Komentarz do zmian 2016. Red. D. ŚwIECKI. Warszawa 2016.

BACHURSKa B.: Dobrowolne poddanie się odpowiedzialności karnej z art. 387 k.p.k. $w$ świetle nowelizacji kodeksu postępowania karnego z dnia 27 września 2013 r. „Ius et Administratio” 2013, z. 4.

BELING E.: Deutches Reichsstrafprozessrecht. Berlin-Lipsk 1928.

Boć J. W: Konstytucje Rzeczpospolitej Polskiej oraz Komentarz do Konstytucji RP z 1997 r. Red. IDEM. Wrocław 1998.

BorucKa-Arctowa M.: Zaufanie do prawa jako wartość spoteczna i rola sprawiedliwości proceduralnej. W: Teoria prawa. Filozofia prawa. Wspótczesne prawo i prawoznawstwo. Torun 1998.

BuŁAT A.: Skazanie w trybach konsensualnych-sposób na przyspieszenie postępowania karnego czy zagrożenie dla interesu oskarżonego?. W: Verba volant, scripta manent. Proces karny, prawo karne skarbowe i prawo wykroczeń po zmianach z lat 2015-2016. Księga pamiątkowa poświęcona Profesor Monice Zbrojewskiej. Red. T. GrzegorczyK, R. OlszewsKi. Warszawa 2017.

CIEślaK M.: Dzieła wybrane. T. II: Polska procedura karna. Podstawowe założenia teoretyczne. W: CieślaK M.: Dzieła wybrane. Red. S. Waltoś. Kraków 2011.

CIEŚlaK M.: O pojęciu przedmiotu procesu karnego i $w$ sprawie tzw. „podstawy procesu”. W: CIEślak M.: Dzieła wybrane. T. IV: Prawo karne procesowe. Artykuty, studia i inne prace. Red. S. Waltoś. Kraków 2011; również w: PiP 1957, z. 8-9.

CIEŚlaK M.: Polskie prawo karne. Zarys systemowego ujęcia. W: CIEśLAK M.: Dzieła wybrane. T. III. Red. S. WaLtoś. Kraków 2011.

CieślaK M.: Proces karny. Zagadnienia podstawowe. Kraków 1952.

CIEŚLAK M.: Zagadnienia dowodowe w procesie karnym. W: CIEśLAK M.: Dzieła wybrane. T. I. Red. S. Waltoś. Kraków 2011.

DĄBKIEWICZ K.: Merytoryczne orzekanie sqadu pierwszej instancji poza rozprawa główna. „Kwartalnik Sądowy Apelacji Gdańskiej” 2016, z. 1.

DiJK van P., Hoof van G.J.H.: Theory and Practice of the European Covnvention on Human Rights. The Hague 1996.

Doda Z., Grajewski J., Murzynowski A.: Kasacja w postępowaniu karnym. Komentarz. Warszawa 1996.

ERECIŃSKI T.: Ograniczenia $w$ dostępności kasacji $w$ sprawach cywilnych. W: Prace z prawa prywatnego. Księa pamiątkowa ku czci Sędziego Janusza Pietrzykowskiego. Red. Z. BANASzczyK. Warszawa 2000.

FInGAS M.: Zakres rozpoznania sprawy przez sąd odwoławczy w przypadku zaskarżenia przez tzw. strone prywatna orzeczenia wydanego $w$ trybie konsensualnym. W: Verba volant, scripta manent. Proces karny, prawo karne skarbowe $i$ prawo wykroczeń po zmianach z lat 2015-2016. Ksiega pamiatkowa poświęcona Profesor Monice Zbrojewskiej. Red. T. GrzegorczyK, R. OlszewsKi. Warszawa 2017.

Furmankiewicz H., Majster M., Penner L.: Akty oskarżenia i rewizje. Warszawa 1955.

GABERLE A.: Zasada trafnej reakcji na przestępstwo a postępowanie uproszczone, przyspieszone i nakazowe. W: Problemy kodyfikacji prawa karnego. Ksiega ku czci Profesora Mariana Cieślaka. Red. S. Waltoś. Kraków 1993. 
Gaberle A., Waltoś S.: Postępowania szczególne w polskim procesie karnym. Model a praktyka. „Zeszyty Naukowe Instytutu Badania Prawa Sądowego”1977, z. 7.

GARDOCKI L.: Prawo karne. Warszawa 2011.

GARLICKI L.: Przesłanki ograniczenia konstytucyjnych praw i wolności (na tle orzecznictwa Trybunału Konstytucyjnego). PiP 2001, z. 10.

GARLICKI L.: Zasada równości i zakaz dyskryminacji $w$ orzecznictwie Trybunału Konstytucyjnego. W: Obywatel - jego wolności i prawa. Red. B. OliwiA-RADZIKOWSKA. Warszawa 1998.

GARLICKI L.: Zasada równości $i$ zakaz dyskryminacji $w$ orzecznictwie Trybunału Konstytucyjnego. W: Obywatel - jego wolności i prawa. Red. B. OliwA-RADZIKowsKa. Warszawa 1998.

GIL D.: Postępowanie $w$ sprawach z oskarżenia prywatnego $w$ polskim procesie karnym. Warszawa 2011.

GLINIECKI W.: Przyspieszanie i upraszczanie postępowania karnego a ochrona interesów pokrzywdzonego. Prok. i Pr. 2007, z. 2.

GostyŃski Z.: Zasada szybkości w nowym Kodeksie postępowania karnego. W: Nowy Kodeks postępowania karnego. Zagadnienia węzłowe. Red. E. SkręTowicz. Kraków 1998.

Grajewski J., Papke-Olszauskas K., Steinborn S., Woźniewski K.: O tak zwanym upraszczaniu procesu karnego. W: Węzłowe problemy procesu karnego. Red. P. Hofmański. Warszawa 2010.

GrajewsKi J., STEINBORN S.: Zasada prawdy materialnej jako granica upraszczania procesu karnego. W: Zasada prawdy materialnej. Materiaty z konferencji. Krasiczyn 15-16 października 2005 r. Red. Z. SobolewsKi, G. Artymiak. Kraków 2006.

Gregorowicz J.: Z problemów logicznych stosowania prawa (Résumé: Application de la Loi: Problémes Logiques). ZNUŁ 1963, seria I, z. 32.

GrzegorczyK T.: Kodeks postępowania karnego oraz ustawa o świadku koronnym. Komentarz. Warszawa 2008.

GrzegorczyK T.: Kodeks postępowania karnego. T. I: Komentarz do art. 1-467. Warszawa 2014.

GrzegorczyK T.: O niektórych uproszczeniach procedury karnej w nowym Kodeksie postępowania karnego. PS 1997, z. 9.

GrzegorczyK T.: Podstawowe kierunki projektowanych zmian procedury karnej. PiP 2012, Z. 11.

GRZEGORCZYK T.: Wniosek oskarżonego o skazanie go bez przeprowadzenia postępowania dowodowego na rozprawie. PS 2001, z. 1.

GrZESZCZYK W.: Główne kierunki zmian kodeksu postępowania karnego (cz. II). Prok. i Pr. 2003, z. 6.

GRZESZCZYK W.: Kasacja w sprawach karnych. Kraków 2001.

GrzeszCZYK W.: Nowa kodyfikacja karna. Kodeks postępowania karnego. Krótkie komentarze. Z. 5. Warszawa 1997.

GrzeszczyK W.: Oczywista bezzasadność kasacji w świetle orzecznictwa Sądu Najwyższego. Prok. i Pr. 2002, z. 11.

HayeK F.A.: Konstytucja wolności. Tłum. M. KuniŃsKI. Warszawa 2006. 
Herzog A: Opinia Aleksandra Herzoga - Prokuratora Prokuratury Generalnej. Model postępowania odwoławczego oraz postępowania $w$ sprawie nadzwyczajnych środków zaskarżenia. „Biuletyn Komisji Kodyfikacyjnej Prawa Karnego” 2010, z. 2.

Hofmański P.: Europejska Konwencja Praw Człowieka i jej znaczenie dla prawa karnego materialnego, procesowego i wykonawczego. Białystok 1993.

HoFMAŃSKI P.: Świadek anonimowy $w$ procesie karnym. PPol 1994, z. 2-3.

HoFMAŃsKi P.: Świadek anonimowy w procesie karnym. Kraków 1998.

Hofmański P., Wróbel A. W: Konwencja o Ochronie Praw Człowieka i Podstawowych Wolności. Komentarz do art. 1-18. T. I. Red. L. GarLICKI. Warszawa 2010.

Hofmański P. W: Konwencja o Ochronie Praw Człowieka i Podstawowych Wolności. Komentarz do art. 19-59 oraz do Protokotów dodatkowych. T. II. Red. L. GARLICKI. Warszawa 2011.

Hofmański P., SAdZIK E., ZgryzeK K.: Kodeks postępowania karnego. T. I: Komentarz do artykutów 1-296. Red. P. HofMAŃsKi. Warszawa 2004.

HofmańsKi P., SADZIK E., ZgRYZeK K.: Kodeks postępowania karnego. T. II: Komentarz do artykułów 297-467 k.p.k. Red. P. HoFmańsKi. Warszawa 2004.

HofMaŃsKi P., ZabŁocki S.: Funkcjonalność postępowania kasacyjnego $w$ świetle nowego kodeksu postępowania karnego. W: Nowa kodyfikacja karna. Kodeks postępowania karnego. Zagadnienia węzłowe. Red. E. Sкrętowicz. Warszawa 1997.

HofMAŃsKi P., ZABŁocKI S.: Świadek anonimowy - niespetnione nadzieje. W: Zasady procesu karnego wobec wyzwań wspótczesności. Księga ku czci Profesora Stanistawa Waltosia. Red. J. CzApsKa et al. Warszawa 2000.

JAsIŃSKI W.: Instytucje skazania bez rozprawy (art. 335 k.p.k.) oraz dobrowolnego poddania się odpowiedzialności karnej (art. 387 k.p.k.) na tle naczelnych zasad procesu karnego. Prok. i Pr. 2005, z. 9.

JAsIŃSKI W.: Porozumienia procesowe $w$ znowelizowanym kodeksie postępowania karnego. Prok. i Pr. 2014, z. 10.

JasińsKi W., Kuźma M.: Granice zaskarżalności porozumień procesowych. W: Współzależność prawa karnego materialnego i procesowego $w$ świetle kodyfikacji karnych z 1997 r. i propozycji ich zmian. Red. Z. ĆWIĄKALSKI, G. ARTYMIAK. Warszawa 2009.

JAśKIEWICZ J.: Poznanie faktów $w$ postępowaniu cywilnym. Warszawa 2013.

JEZUSEK A.: „Domniemanie winy” $w$ prawie karnym materialnym a procesowe domniemanie niewinności. RPEiS 2016, z. 2.

JuRCzyK T.: Prawa jednostki $w$ orzecznictwie Europejskiego Trybunatu Sprawiedliwości. Warszawa 2009.

Kala D.: Tryby szczególne $w$ kodeksie postępowania karnego $w$ świetle poglądów reprezentowanych $w$ doktrynie i judykaturze. Torun 2005.

KalinowsKi S.: Polski proces karny w zarysie. Warszawa 1981.

KlejNowska M.: Ograniczenia sqdu odwoławczego orzekającego w sprawie karnej po wniesieniu środka zaskarżenia. Rzeszów 2008.

Klejnowska M.: Wyjątki od zakazu reformationis in peius. W: Problemy znowelizowanej procedury karnej. Red. Z. Sobolewski, G. Artymiak, C.P. KŁaK. Warszawa 2004. 
Klejnowska M.: Opinia dr hab. Moniki Klejnowskiej - Uniwersytet Rzeszowski. Model postępowania odwoławczego i nadzwyczajnoskargowego $w$ sprawach karnych. „Biuletyn Komisji Kodyfikacyjnej Prawa Karnego” 2010, z. 2.

KlejNowsKa M.: Zasada prawdy materialnej w postępowaniu odwoławczym. W: Zasada prawdy materialnej. Red. Z. SobolewsKi, G. ARTYMiaK. Warszawa 2006.

KuICH-Rump J.: Podstawa faktyczna rozstrzygnięcia sądowego $w$ procesie cywilnym. Warszawa 1977.

KŁODAWsKi M.: Superfluum i nadwyżki znaczeniowe jako przykłady redundancji tekstu prawnego. „Archiwum Filozofii Prawa i Filozofii Społecznej” 2013, z. 2.

KŁopocka-JasińsKa M.: Pojęcie sprawy w świetle art. 6 Konwencji o Ochronie Praw Człowieka i Podstawowych Wolności. „Przegląd Prawa Konstytucyjnego" 2016, z. 3.

KMIECIK R. W: Prawo dowodowe. Zarys wykładu. Red. R. KMIECIK. Kraków 2005.

Kмiecik R. W: R. KмieciK, E. Skrętowicz: Proces karny. Część ogólna. Warszawa 2009.

KмiecIK R.: Glosa do postanowienia Sądu Najwyższego z dnia 29 kwietnia 1997 r., VKKN 266/97. OSP 1997, z. 12.

KмІесік R.: Kasacja jako nadzwyczajny środek zaskarżenia wyroku (kilka uwag de lege ferenda $w$ zwiqzzu z unormowaniami k.p.k. z 1997 r.). W: Polska lat dziewięćdziesiątych. Przemiany państwa i prawa. T. 2. Red. L. Antonowicz et al. Lublin 1998.

KMIECIK R.: O dwu koncepcjach dalszego rozwoju procedury karnej (Uwagi z zwiazku z tzw. konsensualizmem procesowym). W: Aktualne problemy prawa i procesu karnego. Ksiega ofiarowana Profesorowi Janowi Grajewskiemu. Red. M. PŁachta. GSP 2003, t. XI.

KMIEcIK R.: Pokrzywdzony jako oskarżyciel a „sprawiedliwość naprawcza” rys historyczny z perspektywy wspótczesnej. AUMCS 2009/2010, sectio G, vol. LVI/LVII.

KMIECIK R.: Trójinstancyjny system apelacyjno-kasacyjny czy dwuinstancyjna hybryda rewizyjno-kasacyjna?. W: Kierunki i stan reformy prawa karnego. Red. T. Bojarski, E. Skrętowicz. Lublin 1995.

KocIUBIŃsKI W.: Wyłaczenie stosowania zakazu reformationis in peius $w$ wypadkach określonych w art. 60 \$ 3 i 4 kodeksu karnego oraz art. 343 lub art. 387 kodeksu postępowania karnego. Prok. i Pr. 2004, z. 10.

Kolasiński B., Kulikowski T.: Glosa krytyczna do uchwaty Sądu Najwyższego z dnia 20 stycznia 1999 r., I KZP 21/98. Prok. i Pr. 2000, z. 4.

KoŁodzIEJCZYK A.: Pokrzywdzony $w$ charakterze świadka anonimowego. Prok. i Pr. 2007, z. 1.

KOPER R.: Brak watpliwości dotyczacych okoliczności popetnienia przestępstwa i winy jako warunek stosowania regulacji konsensualnych $w$ procesie karnym. W: Verba volant, scripta manent. Proces karny, prawo karne skarbowe i prawo wykroczeń po zmianach z lat 2015-2016. Księga pamiątkowa poświęcona Profesor Monice Zbrojewskiej. Red. T. GrzegorczyK, R. OlszewsKi. Warszawa 2017.

Koper R.: O nowej formie konsensualizmu $w$ procesie karnym (art. 338 a i art. 343 a k.p.k.). Pal. 2014, z. 7-8. 
KoRDIK A.: Kasacja $w$ świetle przepisów nowego kodeksu postępowania karnego. Uwagi dyskusyjne. W: Nowa kodyfikacja prawa karnego. Red. L. Bogunia. Wrocław 1997.

KoścIELNIAK-Marsza乇 M.: Wyrok sądu I instancji. Warszawa 2017.

Kotarbiński T.: Abecadto praktyczności. Warszawa 1974.

KoTARBIŃsKi T.: Hasło dobrej roboty. Warszawa 1975.

KotARbiński T.: Traktat o dobrej robocie. Wrocław-Warszawa-Kraków-Łódź 1982.

KotARbiŃsKi T.: Zasady dobrej roboty. Łódź 1946.

KRUSZYŃsKi P., ZBRoJewsKa M.: Nowy model postępowania karnego ukształtowany nowela do k.p.k. z 27 września 2013 r. Pal. 2014, z. 1-2.

Kryże A.: Nowe instytucje majace wptyw na sprawność postępowania i procedury dowodowej. ,Jurysta” 1999, z. 11 - 12.

LANG W., WróblewsKi J., ZAWADZKi S.: Teoria państwa i prawa. Warszawa 1986.

LASKOWSKI M.: Status pokrzywdzonego w procesie karnym po nowelizacji Kodeksu postępowania karnego z 27 września 2013 r. W: Wielka Nowelizacja procesu karnego. Red. J. Godyń, M. HudzIK, L.K. PAPRZYCKI. Warszawa 2014.

LIPCZYŃSKA M.: Model postępowania kontrolnego w k.p.k. z 1969 r. PiP 1971, z. 2.

ŁABNO A.: Ograniczenie praw i wolności człowieka na podstawie art. 31 Konstytucji III RP. W: Prawo i wolności obywatelskie w Konstytucji RP. Red. B. BanaszaK, A. PreIsner. Warszawa 2002.

ŁAWNICKI J.: Konsensualizm procesowy po nowelizacji Kodeksu postępowania karnego. „Kwartalnik Krajowej Szkoły Sądownictwa i Prokuratury” 2014, z. 3.

ŁAZARSKA A.: Rzetelny proces cywilny. Warszawa 2012.

ŁoJEWSKI K.: Apelacja karna. Warszawa 2003.

MaŁocha-Krupa A.: Słowa $w$ lustrze. Pleonazm-semantyka-pragmatyka. Wrocław 2003.

Marszat K.: Konstytucyjna zasada zaskarżalności decyzji $w$ procesie karnym. „Wojskowy Przegląd Prawniczy” 2007, z. 3.

MARSZAt K.: System apelacyjno-kasacyjny $w$ polskim procesie karnym. SI 1997, z. XXXIII. Red. P. KRUSZYŃSKI.

Marszat K.: Zaskarżalność decyzji wydanych w procesie karnym. PS 2007, z. 3.

McConville M.: The victims of plea bargaininng. W: Zasady procesu karnego wobec wyzwań współczesności. Księga ku czci Profesora Stanisława Waltosia. Red. J. CZAPSKa et al. Warszawa 2000.

MENTEL J.: Wniosek oskarżonego o skazanie bez przeprowadzenia postępowania dowodowego (art. 387 k.p.k.). W: Nowa kodyfikacja prawa karnego. T. 9. Red. L. Bogunia. Wrocław 1997.

MichalsKa-MarciniaK M.: Zasada instancyjności $w$ postępowaniu cywilnym. Warszawa 2012.

MORAwsKi L.: Liberalizm, komunitaryzm i republikanizm. W: L. MorawsKi: Filozofia prawa. Warszawa 2014.

Morawski L.: Prawa jednostki a dobro wspólne (Liberalizm versus komunitaryzm). PiP 1998, z. 11.

Muras Z.: Postępowanie odwoławcze w procesie karnym. Artykuty 425-467 k.p.k. Komentarz. Warszawa 2004. 
MurzYNOwsKi A.: Ogólna charakterystyka nowego Kodeksu postępowania karnego. PiP 1997, z. 9.

MuRZYNOWSKI A.: Refleksje na temat przestrzegania zasady prawdy materialnej a zachowanie sprawności postępowania karnego. W: Aktualne problemy prawa i procesu karnego. Ksiegga ofiarowana Profesorowi Janowi Grajewskiemu. Red. M. PŁachta. GSP 2003, t. XI.

Murzynowski A.: Rozważania na temat modelu kasacji. W: Problemy kodyfikacji prawa karnego. Księga ku czci Profesora Mariana Cieślaka. Red. S. Waltoś. Kraków 1993.

NeTCZUK R.: Świadek anonimowy w polskim procesie karnym (zakres przedmiotowy utajnienia a skuteczność ochrony). PPol 2002, z. 1.

Nowe uregulowania prawne $w$ kodeksie postępowania karnego z 1997 r. Red. P. KRUSZYŃsKi. Warszawa 1999.

Nowicki M.A.: Wokół Konwencji Europejskiej. Komentarz do Europejskiej Konwencji Praw Człowieka. Warszawa 2017.

NowociEń D.: Instytucja „dobrowolnego poddania się karze” $w$ Kodeksie postępowania karnego z 1997 r. W: Nowa kodyfikacja prawa karnego. T. 1. Red. L. BogUnIA. Wrocław 1997.

OpaŁeK K., Wróblewski J.: Zagadnienia teorii prawa. Warszawa 1969.

Ossowska M.: Normy moralne. Próba systematyzacji. Warszawa 1985.

PAPRZYCKI L.K.: Model kasacji w polskiej procedurze karnej. Pal. 2008, z. 7-8.

PAPRZYCKI L.K.: Rzetelność trybów konsensualnych po nowelizacji 2013-2015. W: Wokót gwarancji współczesnego procesu karnego. Księa jubileuszowa Prof. P. Kruszyńskiego. Red. M. Rogacka-Rzewnicka, H. GajewsKa-KraczKowsKa, B.T. BIEŃKOwsKa. Warszawa 2015.

Pawela S.: Względne przyczyny odwoławcze. Warszawa 1970.

PIASECKI K.: Wyrok pierwszej instancji w procesie cywilnym. Warszawa 1981.

Ponikowski R.: Wniosek oskarżonego o wydanie wyroku skazujacego bez przeprowadzenia postępowania dowodowego - art. 387 nowego kodeksu postępowania karnego. W: Nowa kodyfikacja prawa karnego. T. I. Red. L. Bogunia. Wrocław 1997.

Pracki H.: Instytucja świadka anonimowego $w$ orzecznictwie Europejskiego Trybunatu Praw Człowieka w Strasburgu oraz sadów polskich. Prok. i Pr. 2003, Z. 2.

Pradel J.: Rzetelny proces $w$ Europejskim prawie karnym. Prok. i Pr. 1996, z. 9.

PszczóŁкowski T.: Dylematy sprawnego działania. Warszawa 1982.

PszczóŁKowski T.: Zasady sprawnego działania. Warszawa 1975.

Radoniewicz F.: Prawo do sadu w Europejskiej Konwencji Praw Człowieka, Karcie Praw Podstawowych Unii Europejskiej oraz Konstytucji Rzeczpospolitej Polskiejzagadnienia wybrane (cz. I). „Przegląd Prawa Konstytucyjnego” 2017, z. 2.

RAU Z.: Liberalizm. Zarys myśli politycznej XIX i XX wieku. Warszawa 2000.

RAwls J.: Liberalizm polityczny. Tłum. A. Romaniuk. Warszawa 1998.

Rawls J.: Teoria sprawiedliwości. Tłum. M. Panufnik, J. Pasek, A. Romaniuk. Warszawa 1994.

RogacKa-RzeWnicka M.: Kasacja w polskim procesie karnym. Warszawa 2001. 
RogacKa-RzewnicKa M.: Obrońca $i$ petnomocnik wobec instytucji dobrowolnego poddania się karze. W: Obrońca $i$ petnomocnik $w$ procesie karnym po 1 lipca 2013 r. Przewodnik po zmianach. Red. P. WiLIŃski. Warszawa 2015.

Rogoziński P.: Dobrowolne poddanie się przez oskarżonego odpowiedzialności karnej. PiP 2000, z. 9.

RYLSKI P.: Dziatanie sq̨du z urzędu a podstawa faktyczna wyroku cywilnego. Warszawa 2009.

SADURSKI W.: Neoliberalny system wartości politycznych. Warszawa 1980.

SAUER W.: Grundlagen des Prozessrechts. Stuttgart 1929; inne miejsce publikacji: „Scientia Verlag” 1970 (przedruk wydania z 1929 r.).

Schaff L.: Wszczęcie postępowania karnego a problem podstawy i przedmiotu proсеsu. PiP 1959, z. 2.

SCHAFF L.: Zakres i formy postępowania przygotowawczego. Warszawa 1961.

SIEDLECKI W.: Zarys postępowania cywilnego. Warszawa 1966.

SiEDlECKI W.: Zasady wyrokowania $w$ procesie cywilnym. Warszawa 1957.

SIERACKI W.: Próba określenia zakresu części wyroku „dotyczącej orzeczenia o winie” (art. 395 k.p.k.). „Wojskowy Przegląd Prawniczy” 1994, z. 1.

SKRĘTOWICZ E.: Charakter prawny orzeczenia warunkowo umarzajacego postępowanie karne $w$ świetle zasady domniemania niewinności. W: Współczesny polski proces karny. Ksiega ofiarowana Profesorowi Tadeuszowi Nowakowi. Red. S. STACHOWIaK. Poznań 2002.

STEFAŃSKa B.J.: Skazanie na posiedzeniu bez przeprowadzania postępowania dowodowego. W: Verba volant, scripta manent. Proces karny, prawo karne skarbowe i prawo wykroczeń po zmianach z lat 2015-2016. Ksiega pamiatkowa poświęcona Profesor Monice Zbrojewskiej. Red. T. GrzegorczyK, R. OlszewsKi. Warszawa 2017.

STEFAŃSKI R.A.: Krytycznie o obecnym modelu postępowania przygotowawczego. W: Węzłowe problemy procesu karnego. Red. P. Hofmański. Warszawa 2010.

STEFAŃsKi R.A.: Przyszły model postępowania przygotowawczego. IN 2009, z. 1.

STEFAŃSKI R.A.: Skazanie bez rozprawy znowelizowanym kodeksie postępowania karnego. Prok. i Pr. 2003, z. 6.

STEINBORN S.: Ograniczenia zaskarżalności wyroku wydanego w I instancji jako środek uproszczenia procesu karnego $w$ świetle prawa do dwuinstancyjnego postępowania (uwag de lege lata $i$ de lege ferenda). W: Prawa człowieka: wczorajdziś - jutro. Red. J. ZaJADŁo. GSP 2005, t. XIII.

STEINBorn S.: Porozumienia $w$ polskim procesie karnym. Warszawa 2005.

STEINBORn S.: Prawomocność części orzeczenia w procesie karnym. Warszawa 2011.

STEINBORN S.: Sprawozdanie z dyskusji podczas konferencji „Model postępowania odwoławczego i kasacyjnego" - Warszawa 28 września 2010 r. (analiza problemowa). „Biuletyn Komisji Kodyfikacyjnej Prawa Karnego” 2010, z. 2.

SzKLARCZYK A.: Przedmiotowy zakres utajnienia świadka anonimowego na tle przepisów ustawy nowelizującej kodeks postępowania karnego z 10 stycznia 2003 r. Probl. Prawa Karnego 2004, z. 25.

SzYProwski B.: Glosa do uchwały Sądu Najwyższego z dnia 20 stycznia 1999 r., I KZP 21/98. OSP 1999, z. 9. 
ŚwiATŁowsKi A.: Jedna czy wiele procedur karnych. Z zagadnień wewnętrznego zróżnicowania form postępowania karnego rozpoznawczego. Sopot 2009.

ŚwiatŁowsKi A.: Glosa do wyroku Trybunatu Konstytucyjnego z dnia 17 maja 2004 r., SK 32/03. Prok. i Pr. 2005, z. 5.

ŚwIECKI D.: Granice orzekania na niekorzyść oskarżonego na podstawie art. $434 \$ 1$ i art. 443 k.p.k. PS 2009.

ŚwIECKI D.: Wina w prawie karnym materialnym i procesowym. Prok. i Pr. 2009, Z. $11-12$.

TęCZA-PACIOREK A.: Zasada domniemania niewinności $w$ polskim procesie karnym. Warszawa 2012.

TOKARCZYK R.A.: Filozofia prawa w perspektywie prawa natury. Białystok 1997.

TOKARCzYK R.A.: Prawo natury jako uniwersalna podstawa ładu społecznego. W: Filozofia prawa a tworzenie $i$ stosowanie prawa. Materiały Ogólnopolskiej Konferencji Naukowej zorganizowanej w dniach 11 i 12 czerwca 1991 r. $w$ Katowicach. Red. B. CzecH. Katowice 1992.

TrechSel S.: Human Rights and Criminal Proceedings. New York 2005.

Tylman J.: Dylematy instytucji świadka incognito. W: Współczesny polski proces karny. Ksiega ofiarowana Profesorowi Tadeuszowi Nowakowi. Red. S. STACHowiak. Poznań 2002.

Tylman J.: Instytucja świadka incognito. AUL 1997, t. 65.

TyszKa T.: Prakseologia podejmowania decyzji. „Prakseologia” 1977, z. 1-2.

WALIGórski M.: Podstawy kasacyjne procesu cywilnego $w$ świetle różnicy pomiędzy faktem i prawem. Lwów 1936.

Waltoś S.: Dylematy ochrony świadka w procesie karnym. PiP 1995, z. 4.

Waltoś S.: Główne nurty nowelizacji procedury karnej. PiP 2003, z. 4.

Waltoś S.: Nowa polska procedura karna a oczekiwania społeczne. PiP 1998, z. 9-10.

Wasilewski A.: Prawo do sadu w sprawach dyscyplinarnych (ustawodawstwo polskie na tle standardów Europejskiej Konwencji Praw Człowieka i Podstawowych Wolności oraz Konstytucji). PS 2001, z. 9.

WAsIUTYŃsKi Z.: O zasadach najmniejszego i największego wysitku i o współzawodnictwie. „Prakseologia” 1971, z. 39-40.

WASSERMAN W.: Zasady formułowania zarzutów apelacyjnych $w$ obowiąujacej procedurze karnej. Prok. i Pr. 2010, z. 6.

WASZCZYŃSKI J.: O podstawach rewizji wedtug k.p.k. ZNUŁ 1959, seria I, z. 14.

WĄSEK A.: Krytyczne uwagi do wyroku Trybunatu Konstytucyjnego z dnia 16 maja 2000, P 1/99, dotyczacego warunkowego umorzenia postępowania karnego. W: Współczesny polski proces karny. Księga ofiarowana Profesorowi Tadeuszowi Nowakowi. Red. S. StachowiaK. Poznań 2002.

WĄSEK A.: O niektórych niespójnościach unormowań kodeksu karnego i kodeksu postępowania karnego. W: Aktualne problemy prawa i procesu karnego. Ksiega ofiarowana Profesorowi Janowi Grajewskiemu. Red. M. PŁAchtA. GSP 2003, T. XI.

WĄSEK A.: Świadek anonimowy $w$ rzetelnym procesie karnym. W: Kierunki i stan reformy prawa karnego. Red. T. BoJARSKI, E. SKRĘTOWICZ. Lublin 1995. 
WĄSEK-WIADEREK M.: Zastosowanie gwarancji art. 6 Europejskiej Konwencji Praw Człowieka do postępowań dyscyplinarnych (ze szczególnym uwzględnieniem odpowiedzialności dyscyplinarnej zawodów prawniczych). Rej. 2010, wyd. specjalne.

WiLIŃski P.: Proces karny w świetle Konstytucji. Warszawa 2011.

WILIŃsKi P.: Świadek incognito $w$ polskim procesie karnym. Kraków 2003.

WiLIŃsKi P.: Zasada prawa do obrony w polskim procesie karnym. Kraków 2006.

WILK L.: Instytucja skróconej rozprawy jako przykład konsensualnego zakończenia procesu karnego - art. 387 k.p.k.. Prok. i Pr. 2005, z. 1.

WILK L.: Instytucja skróconej rozprawy w trybie art. 387 k.p.k. PS 2005, z. 1.

WinczoreK P.: Komentarz do Konstytucji Rzeczpospolitej Polskiej z dnia 2 kwietnia 1997 r. Warszawa 2000.

Winczorek P.: Prawo konstytucyjne Rzeczpospolitej Polskiej. Warszawa 2003.

WojTyсzек K.: Granice ingerencji ustawodawczej $w$ sferę praw człowieka w Konstytucji RP. Kraków 1999.

WojtyczeK K.: Zasada proporcjonalności. W: Prawo i wolności obywatelskie $w$ Konstytucji RP. Red. B. BANaszaK, A. PreISNER. Warszawa 2002.

WoźNIAK Ł.: Glosa aprobująca do uchwaty Sądu Najwyższego z dnia 20 stycznia 1999 r., I KZP 21/98. OSP 1999, z. 6.

WoźNIAK Ł.: Zasada domniemania niewinności - zagadnienia podstawowe. W: Zasady procesu karnego wobec wyzwań wspótczesności. Księga ku czci Profesora Stanisława Waltosia. Red. J. CzAPSKA et al. Warszawa 2000.

WójcicKA B.: Kilka uwag na temat zmian dotyczacych sytuacji pokrzywdzonego $w$ procesie karnym. W: Polski proces karny $i$ materialne prawo karne $w$ świetle nowelizacji z 2013 r. Ksiega jubileuszowa dedykowana Profesorowi Januszowi Tylmanowi z okazji Jego 90. Urodzin. Red. T. GrzegorczyK, J. IzydorczyK, R. OlszewsKi. Warszawa 2014.

Wójcicka B.: Sytuacja pokrzywdzonego $w$ procesie karnym po zmianach $w$ prawie karnym w latach 2015-2016 (wybrane zagadnienia). W: Verba volant, scripta manent. Proces karny, prawo karne skarbowe i prawo wykroczeń po zmianach z lat 2015-2016. Księga pamiątkowa poświęcona Profesor Monice Zbrojewskiej. Red. T. GrzegorczyK, R. OlszewsKi. Warszawa 2017.

WRóBlEWSKI J.: Sądowe stosowanie prawa. Warszawa 1972.

Wróblewski J.: O tak zwanym sylogizmie prawniczym. W: Zagadnienia prawa karnego i teorii prawa. Ksiega pamiatkowa ku czci Profesora W. Woltera. Warszawa 1959.

WróblewsKi J.: Stosowanie prawa (model teoretyczny). PiP 1967, z. 6; również w: Wróblewski J.: Pisma wybrane. Red. M. ZirK-SAdowsKi. Warszawa 2015.

WróbleWsKi J.: Wartości a decyzja sq̨dowa. Wrocław 1973.

WróbleWski J.: Zmiany społeczne a prawo. PiP 1984, z. 11.

WYRZYKOWSKI M.: Granice praw i wolności - granice władzy. W: Obywatel - jego wolności i prawa. Red. B. Oliwa-RadziKowska. Warszawa 1998.

ZabŁocKI S.: Ograniczenie zakazu reformationis in peius. Pal. 2003, z. 7-8.

ZAвŁOCKI S.: Procesowe aspekty instrumentalnych poczynań tzw. matego świadka koronnego, ze szczególnym uwzględnieniem zakazu reformationis in peius. W: Współczesne problemy procesu karnego i wymiaru sprawiedliwości. Księga ku czci prof. Kazimierza Marszała. Red. P. Hofmański, K. ZgryzeK. Katowice 2003. 
Zachuta A.: Proces karny skrócony. Pal. 2000, z. 7-8.

ZAGRODNIK J.: Model interakcji postępowania przygotowawczego oraz postępowania głównego w procesie karnym. Warszawa 2013.

Zagubiona szybkość procesu karnego. Jak ja przywrócić?. Red. S. WaLtoś, J. CzAPsKA. Warszawa 2005.

Zagubiona szybkość procesu karnego. Światło w tunelu. Red. S. Waltoś, J. CzAPSKA. Warszawa 2007.

Uzasadnienie do projektu Kodeksu karnego i Kodeksu postępowania karnego. W: Kodeks karny. Kodeks postępowania karnego. Kodeks karny wykonawczy: nowe kodeksy karne - z 1997 r. z uzasadnieniami. Red. I. Fredrich-Michalska, B. STACHURSKA-MarcińcZaK. Warszawa 1997.

ZвRojewsKa M.: Dobrowolne poddanie się karze w kodeksie postępowania karnego. Białystok 2002.

Zвrojewsкa M.: Dobrowolne poddanie się karze $w$ świetle orzecznictwa Sądu Najwyższego. PS 2001, z. 11-12.

ZвRojewsKa M.: Rola i stanowisko prawne Sądu Najwyższego w procesie karnym. Warszawa 2013.

Ziemba Z.: Logika deontyczna jako formalizacja rozumowań normatywnych. Warszawa 1969.

ZIEMBIŃski Z.: O pojmowaniu pozytywizmu i prawa natury. Poznań 1993.

\section{Źródła internetowe}

Uzasadnienie rządowego projektu ustawy o zmianie ustawy Kodeks postępowania karnego, ustawy - Kodeks karny i niektórych innych ustaw (Druk Sejmowy nr 870). Źródło: http://www.sejm.gov.pl/Sejm7.nsf/druk.xsp?nr=870 [dostęp: 27.09.2018]. 